\title{
Intensive Pedestrian Survey of Selected Areas Within McAllister Park, San Antonio, Bexar County, Texas
}

Antonia L. Figueroa

Center for Archeological Research, University of Texas at San Antonio

Joseph M. Thompson

Follow this and additional works at: https://scholarworks.sfasu.edu/ita

Part of the American Material Culture Commons, Archaeological Anthropology Commons, Environmental Studies Commons, Other American Studies Commons, Other Arts and Humanities Commons, Other History of Art, Architecture, and Archaeology Commons, and the United States History Commons

Tell us how this article helped you.

This Article is brought to you for free and open access by the Center for Regional Heritage Research at SFA ScholarWorks. It has been accepted for inclusion in Index of Texas Archaeology: Open Access Gray Literature from the Lone Star State by an authorized editor of SFA ScholarWorks. For more information, please contact cdsscholarworks@sfasu.edu. 


\section{Intensive Pedestrian Survey of Selected Areas Within McAllister Park, San Antonio, Bexar County, Texas}

\section{Creative Commons License}

\section{(c) (1) \&}

This work is licensed under a Creative Commons Attribution-NonCommercial 4.0 International License 


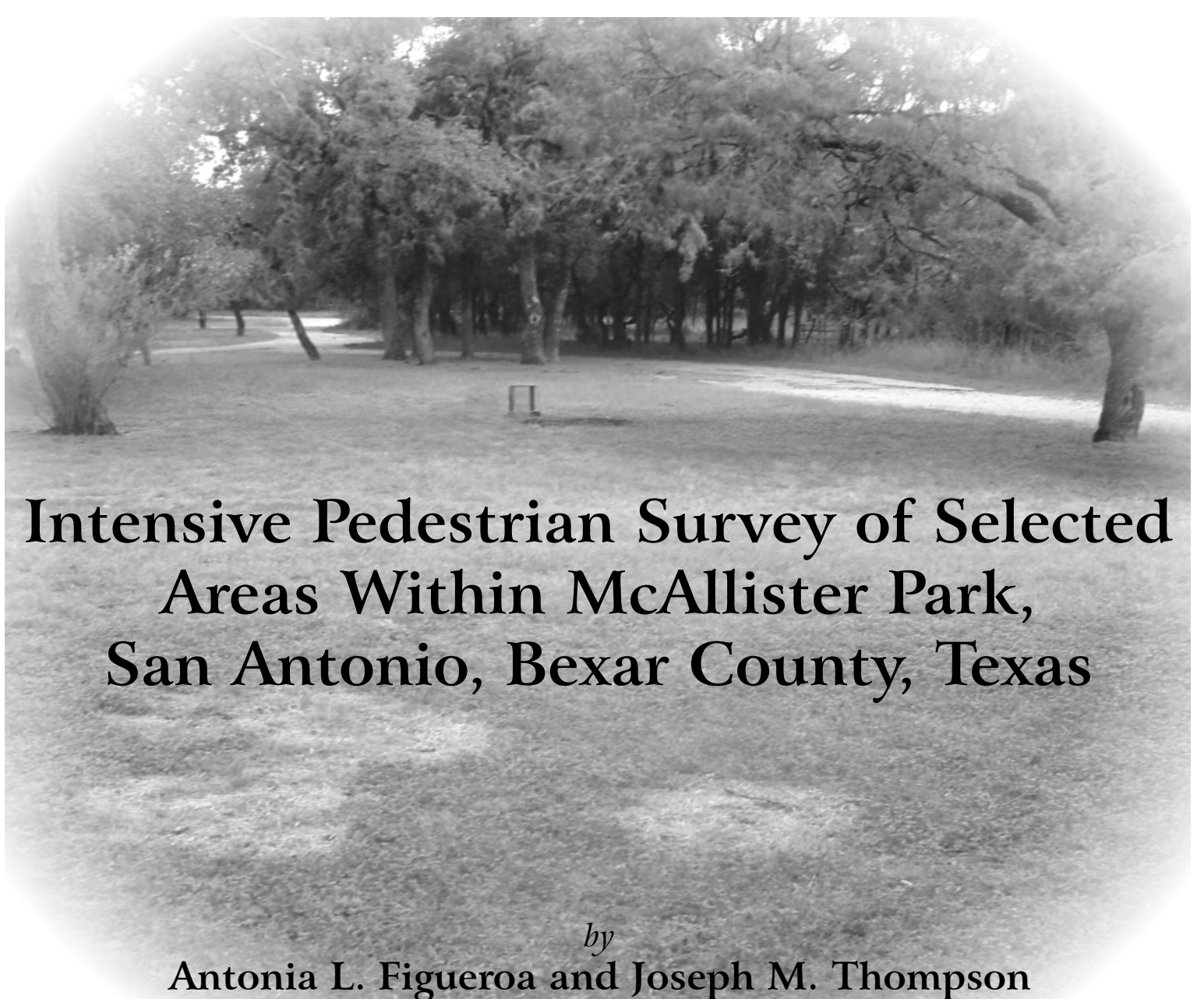

Steve A. Tomka

Principal Investigator

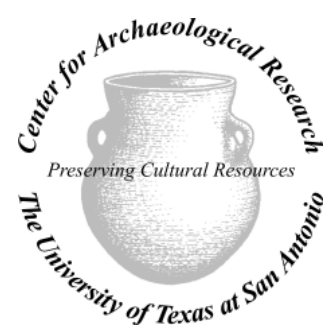

Center for Archaeological Research

The University of Texas at San Antonio

Archaeological Report, No. 362 


\title{
Intensive Pedestrian Survey of Selected Areas Within McAllister Park, San Antonio, Bexar County, Texas
}

\author{
by \\ Antonia L. Figueroa and Joseph M. Thompson
}

Texas Antiquities Permit No. 3905

Steve A. Tomka

Principal Investigator

Prepared for

Parks and Recreation Department

City of San Antonio

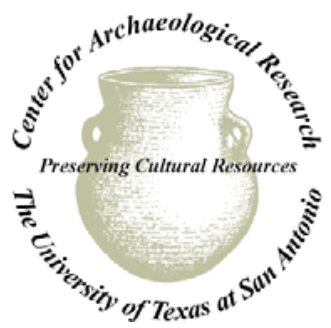

Prepared by

Center for Archaeological Research

The University of Texas at San Antonio

Archaeological Report, No. 362

(C) 2005 
A list of publications offered by the Center for Archaeological Research is available. Call (210) 458-4378; write to the Center for Archaeological Research, The University of Texas at San Antonio, 6900 N. Loop 1604 W., San Antonio, Texas 78249-0658; e-mail to car@utsa.edu; or visit CAR's web site at http://car.utsa.edu. 


\section{Abstract}

Between September 19 and 22, 2005 the Center for Archaeological Research (CAR) of The University of Texas at San Antonio conducted a 100 percent intensive pedestrian survey within McAllister Park for the Parks and Recreation Department of the City of San Antonio. The survey was followed by an interview with Mr. Marvin Klar, a long-time resident of San Antonio and former owner of much of the land that is now part of McAllister Park. The Parks and Recreation Department is planning a series of improvements to existing facilities and the construction of new facilities within the boundaries of McAllister Park. Eleven separate areas will be impacted by these construction activities.

The goals of the pedestrian survey conducted by CAR were to identify and document all prehistoric and/or historic archaeological sites that may be impacted by the proposed improvements. Eight of the eleven areas were subject to the pedestrian survey. Artifacts constituting isolated finds were not collected unless they were temporally diagnostic. Archaeological investigations of the project area resulted in the location of two isolated finds in Areas 1 and 8 and the inspection of the northern boundary of site 41BX959, present in the southern portion of Area 9.

Additional work is not recommeded in association with the proposed improvements that are planned within McAllister Park. The deposits of site 41BX959 have been disturbed by earth moving activities, and therefore have little to no research potential. The portion of the site located in Area 9 is not recommended for listing to the National Register of Historic Places or for designation as a State Archaeological Landmark. 


\section{Table of Contents}

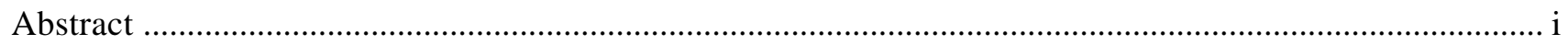

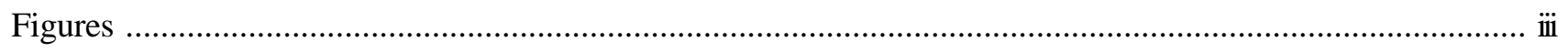

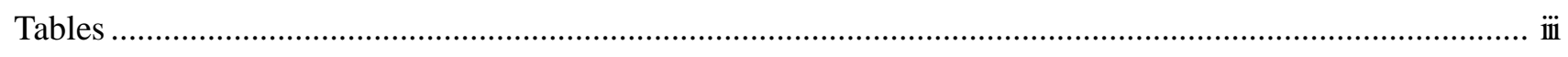

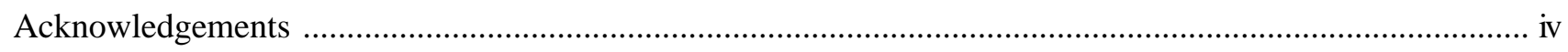

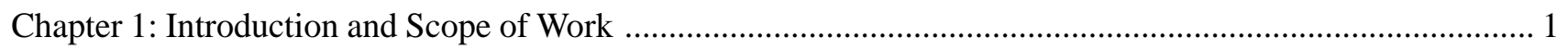

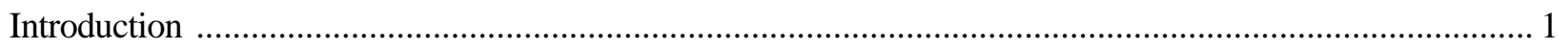

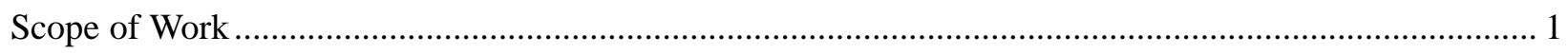

Chapter 2: Environmental Setting and Previous Archaeology .................................................................. 11

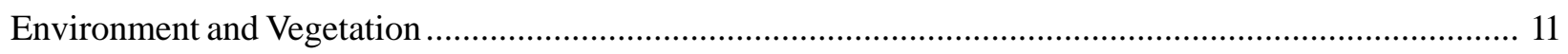

Previous Archaeological Investigations in McAllister Park .................................................................. 11

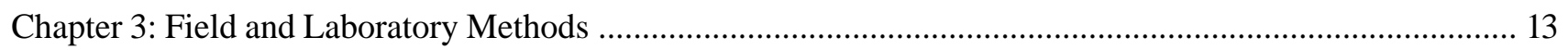

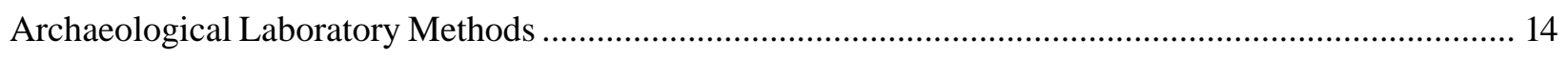

Chapter 4: Results of Field Investigations and Oral History Interview .................................................... 15

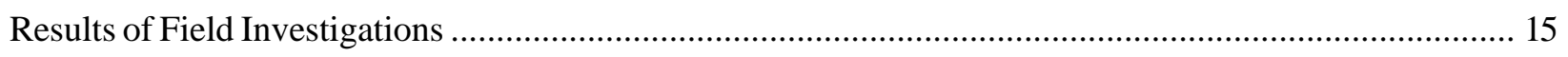

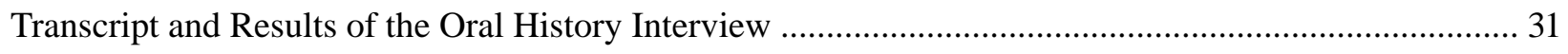

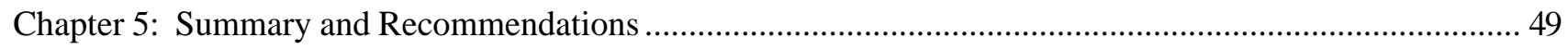

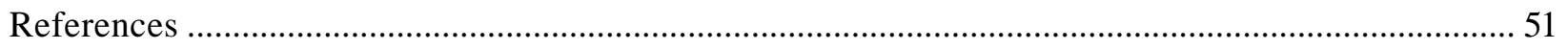




\section{Figures}

Figure 1-1. Location of project area in north-central Bexar County, Texas.

Figure 1-2. Map of McAllister Park showing individual project areas (highlighted areas indicate where archaeological survey was conducted).

Figure 1-3. Parking lot and sidewalks in the vicinity of the new pavilion and playground in Area 1. ............................... 4

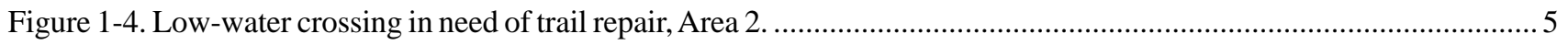

Figure 1-5. Undeveloped scrub vegetation in the area of the planned pedestrian trail, Area 3 ..........................................5

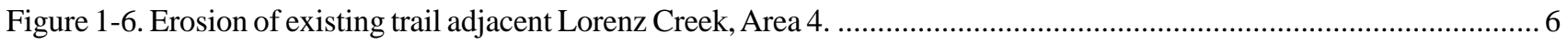

Figure 1-7. Narrow overflow parking area along existing Buckhorn Drive, Area 5 ...................................................... 7

Figure 1-8. Community garden area within Area 6. The pavilion and playground will be relocated to this vicinity. .............. 7

Figure 1-9. Low-water crossing of Lorenz Creek in Area 7. Note erosion at base of sidewalk. .......................................... 8

Figure 1-10. Existing dirt-covered parking lot adjacent lower Bee Tree Drive. Expansion will be into the tree-covered

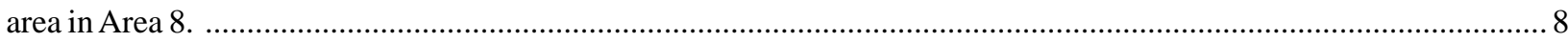

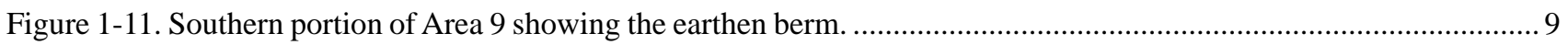

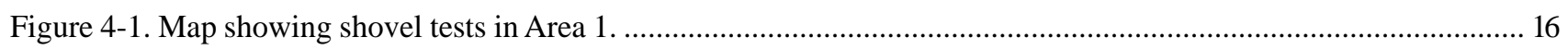

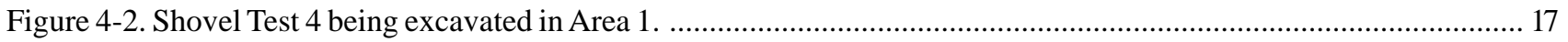

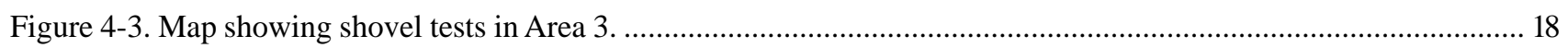

Figure 4-4. Bedrock that was encountered in Shovel Test 44 in Area 3 .................................................................. 18

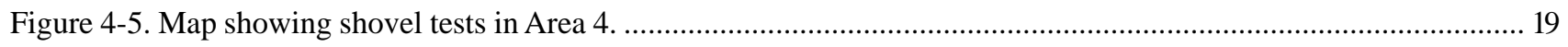

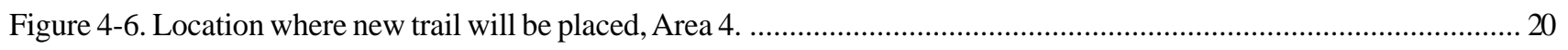

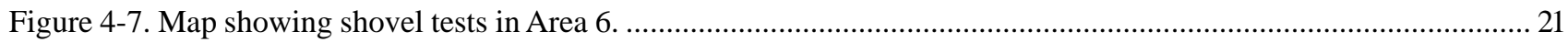

Figure 4-8. Flagging tape that marks positive Shovel Test 39 in Area 6. ..................................................................... 22

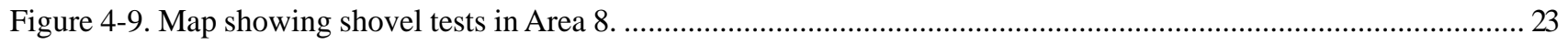

Figure 4-10. Vegetation in Area 8, the proposed parking lot adjacent to lower Bee Tree Drive....................................... 23

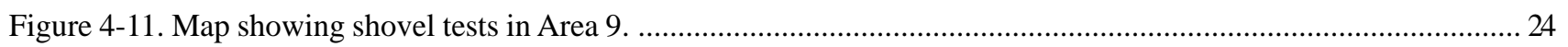

Figure 4-12. Earthen berm and power lines located in the eastern portion of Area 9.................................................... 25

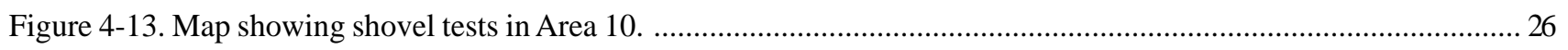

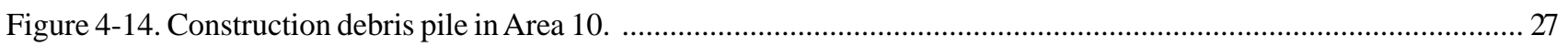

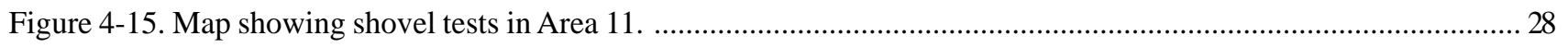

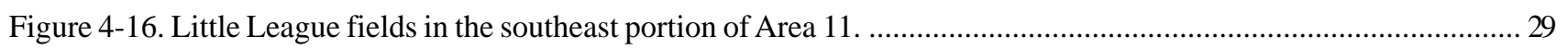

Figure 4-17. Construction debris and disturbance along the proposed water line in the northwest portion of Area 11 ...... 29

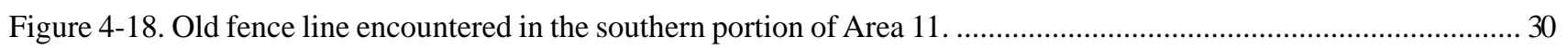

Figure 4-19. Area 11 depicted on the 1953 Longhorn, Texas 7.5' USGS topographic quadrangle map. ............................. 30

\section{Tables}

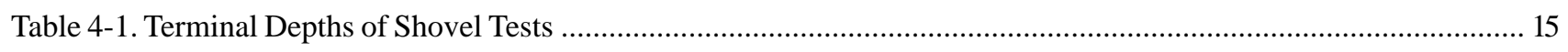

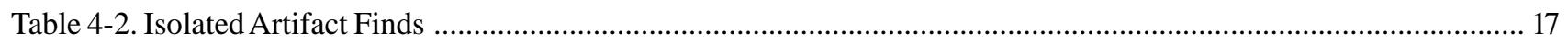




\section{Acknowledgments}

The authors would like to thank Steve Uncapher from the Parks and Recreation Department of the City of San Antonio for his assistance throughout the project. Our gratitude is also extended to Mr. Marvin Klar for his kind participation in the oral history portion of this project. The time and resources Mr. Klar donated to this project are much appreciated. We would also like to acknowledge Albert Fernandez Jr. of the C. F. Zavala Group for providing the maps of the areas to be impacted by construction. The authors would also like to thank Dr. Steve Tomka, who served as the Principal Investigator on the project, for his assistance and comments during the production of the draft report. Antonia Figueroa served as the project archaeologist. Thanks to Jon Dowling and Daniel Teague for serving as diligent crew members, despite the extreme Texas heat. Richard Young and Bruce Moses prepared the graphics for the project and the final report was edited by Claudia Branton. 


\section{Chapter 1: Introduction and Scope of Work}

The Parks and Recreation Department of the City of San Antonio (the Client) is planning a series of improvements to existing facilities and the construction of new facilities within the boundaries of McAllister Park, in north-central Bexar County, Texas (Figure 1-1). McAllister Park is owned and maintained by the Parks and Recreation Department of the City of San Antonio. Because the park is city owned and the proposed improvements project is funded by the City of San Antonio, cultural resources compliance under the Antiquities Code of Texas (Title 9, Chapter 191 of the Texas Natural Resources Code), required the completion of a 100 percent pedestrian survey of previously un-surveyed areas that were to be impacted by the planned improvements.

To conduct the cultural resources compliance work, the Parks and Recreation Department contracted the Center of Archaeological Research to identify and document all prehistoric and/or historic archaeological sites that may be impacted by the proposed improvements. The 100 percent pedestrian survey of the eight areas within the park was conducted by CAR between September 19 and 22, 2005. There are 11 areas of McAllister Park that will be affected by the proposed improvements; three of the areas did not warrant archaeological investigations. This report discusses the results of the archaeological survey conducted at McAllister Park. The archaeological work was conducted under Texas Antiquities Committee (TAC) Permit \#3905. Dr. Steve Tomka served as Principal Investigator.

The remainder of this chapter will discuss the proposed improvements planned for McAllister Park by area. Chapter 2 will discuss the environmental setting of McAllister Park and the previous archaeology conducted in the environs of the project area. Field and lab methods employed for the archaeological investigations will be reviewed in Chapter 3. Chapter 4 will include the results of the field investigations and the transcriptions of the oral history interview conducted with Mr. Marvin Klar. Summary and recommendations will be discussed in Chapter 5 .

\section{Scope of Work}

McAllister Park is located northeast of the intersection of Jones-Maltsberger Road and Starcrest Drive, north of the San Antonio International Airport. The proposed improvements are part of the Parks and Recreation Department's long-range plan to maintain, improve, and expand existing park facilities within the City of San Antonio.

The park improvements consist of two principal elements: the McAllister Park Improvements and the construction of Regional Youth Sports Practice Fields. The McAllister Park Improvements portion consists of the following principal enhancements:

1) Repair of three creek banks and trails crossing creek bottoms;

2) Construction of a pedestrian asphalt trail linking Jones-Maltsberger to a new pavilion and playground;

3) Construction of the pavilion and playground;

4) Improvements to the Optimist Park/Pavilion \# 2 Restroom;

5) Improvements to the $\mathrm{Al}$ Becken Pavilion;

6) Construction of a parking lot adjacent to lower Bee Tree Road; and

7) Construction of a dog park in the south-central portion of the park.

The Regional Youth Sports Practice Fields portion of the project will involve the construction of a number of multipurpose sports practice fields. There are a total of eleven Areas of Potential Effect (APE) that lie within the McAllister Park Improvements and the construction of the Regional Youth Sports Practice Fields (Figure 1-2), but only eight were to be included in the archaeological survey (Figure 1-2). CAR had visited the project area, prior to the fieldwork, with a representative of the Parks and Recreation Department (Steve Uncapher) to assess the scope of the project, each individual impact area and the nature of the proposed disturbances. What follows is a description of each area and the proposed improvements that are planned for each, (refer to Figure 1-2).

Area 1 is located in the northern portion of the park, adjacent to Turkey Roost Drive. Proposed improvements in this area 


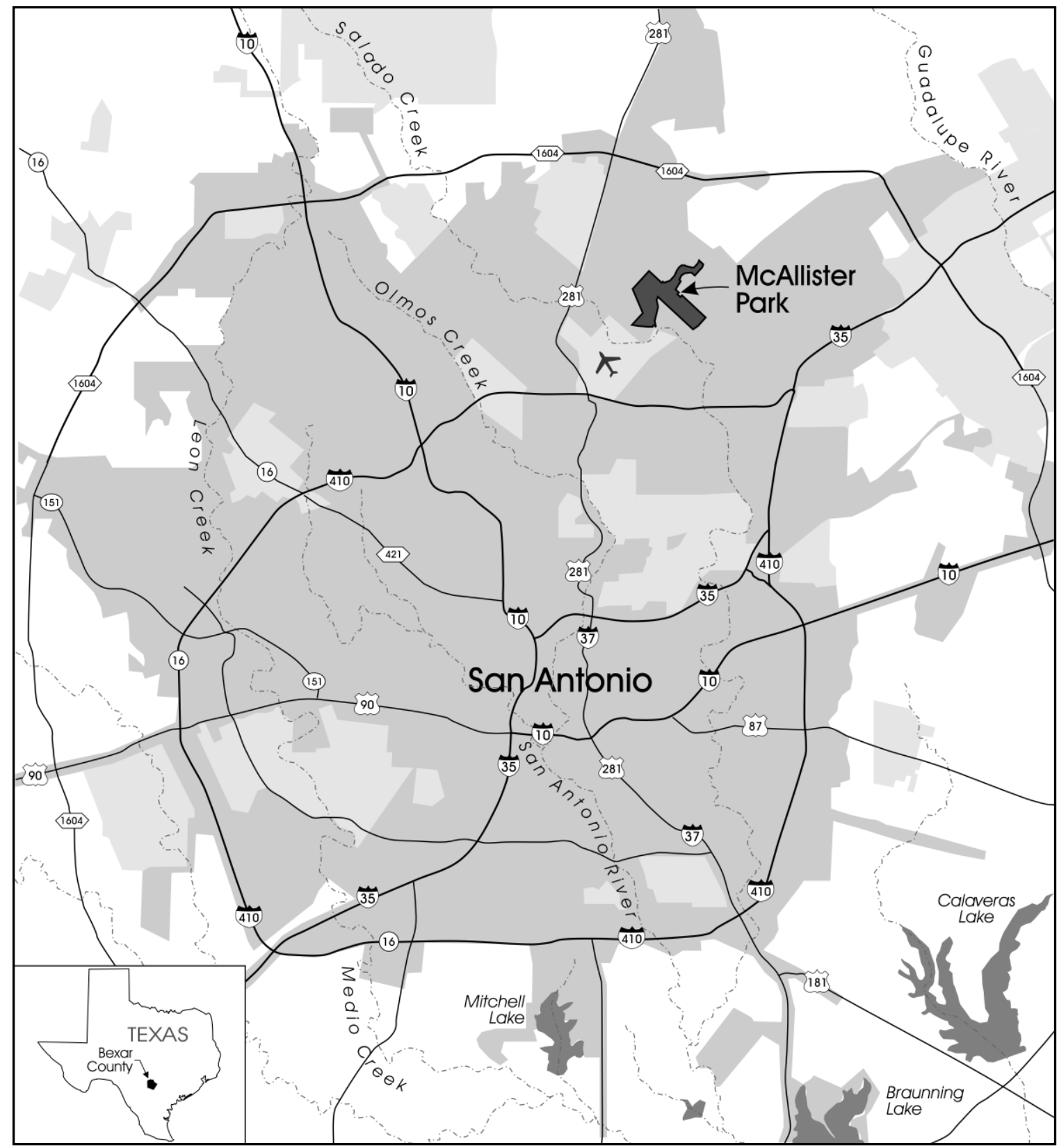

Figure 1-1. Location of project area in north-central Bexar County, Texas. 


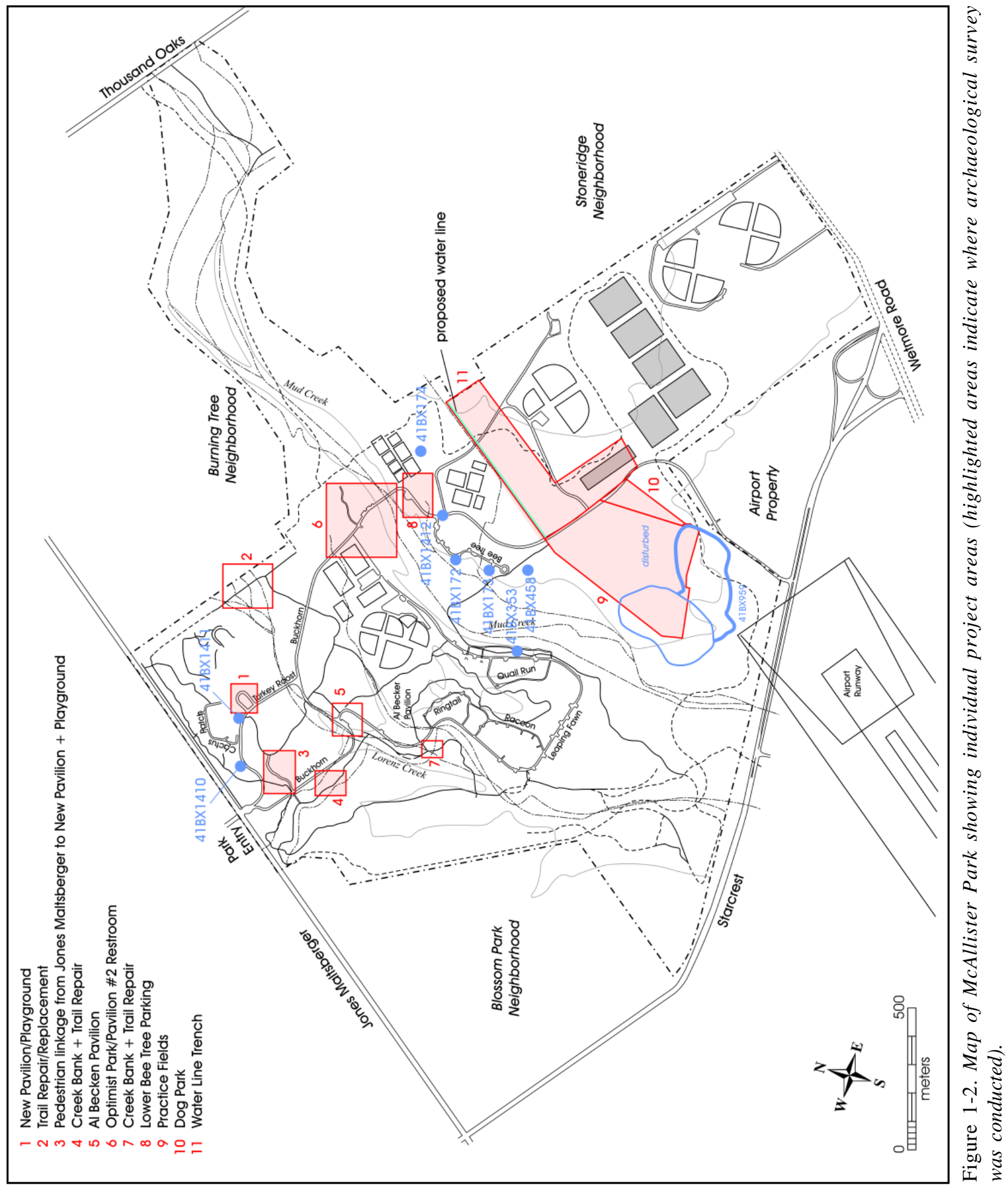


consist of a new playground and pavilion. Area 1 occupies a rectangular area measuring approximately $1 / 3$ acre. Systems of concrete sidewalks connecting existing parking lots with restroom facilities are present within this area (Figure 1-3). In addition, site 41BX1411 lies just to the west of the APE (Figure 1-2). It was recorded in 1999 along the center of the right-of-way (ROW) for a proposed park road (Turkey Roost). The site was a small (13-x-10-m) lithic scatter, lacking in subsurface deposits. It was not recommended for listing to the National Register of Historic Places (NRHP) and designation as a State Archaeological Landmark (SAL) and was impacted during road construction.

Area 2 also is located in the northern portion of the park. The existing trail crosses Lorenz Creek and is eroding as a result (Figure 1-4). The proposed improvements consist of repaving the trail with asphalt. Evidence of cultural material such as lithic debitage and cores has been observed in this part of the creek channel. They have been brought there by erosion and water transport from unknown localities upstream. Trail repair will not impact the creek banks; therefore, archaeological investigations were not proposed for Area 2.

Area 3 is located east of Buckhorn Drive, near the JonesMaltsberger entrance to the park. The proposed improvements in this area will consist of the construction of a pedestrian asphalt trail linking Buckhorn Drive to the new pavilion and playground. The area is underdeveloped scrubland covered by grasses and mesquite (Figure 1-5). The proposed trail is approximately $170 \mathrm{~m}$ in length and has a 3.5-m wide ROW.

Area 4 is located just off Buckhorn Drive in the northwestern portion of the park. The existing trail runs along Lorenz Creek and is eroding (Figure 1-6). Proposed improvements in this area consist of realigning a portion of the existing trail away from the creek channel. The proposed trail will be

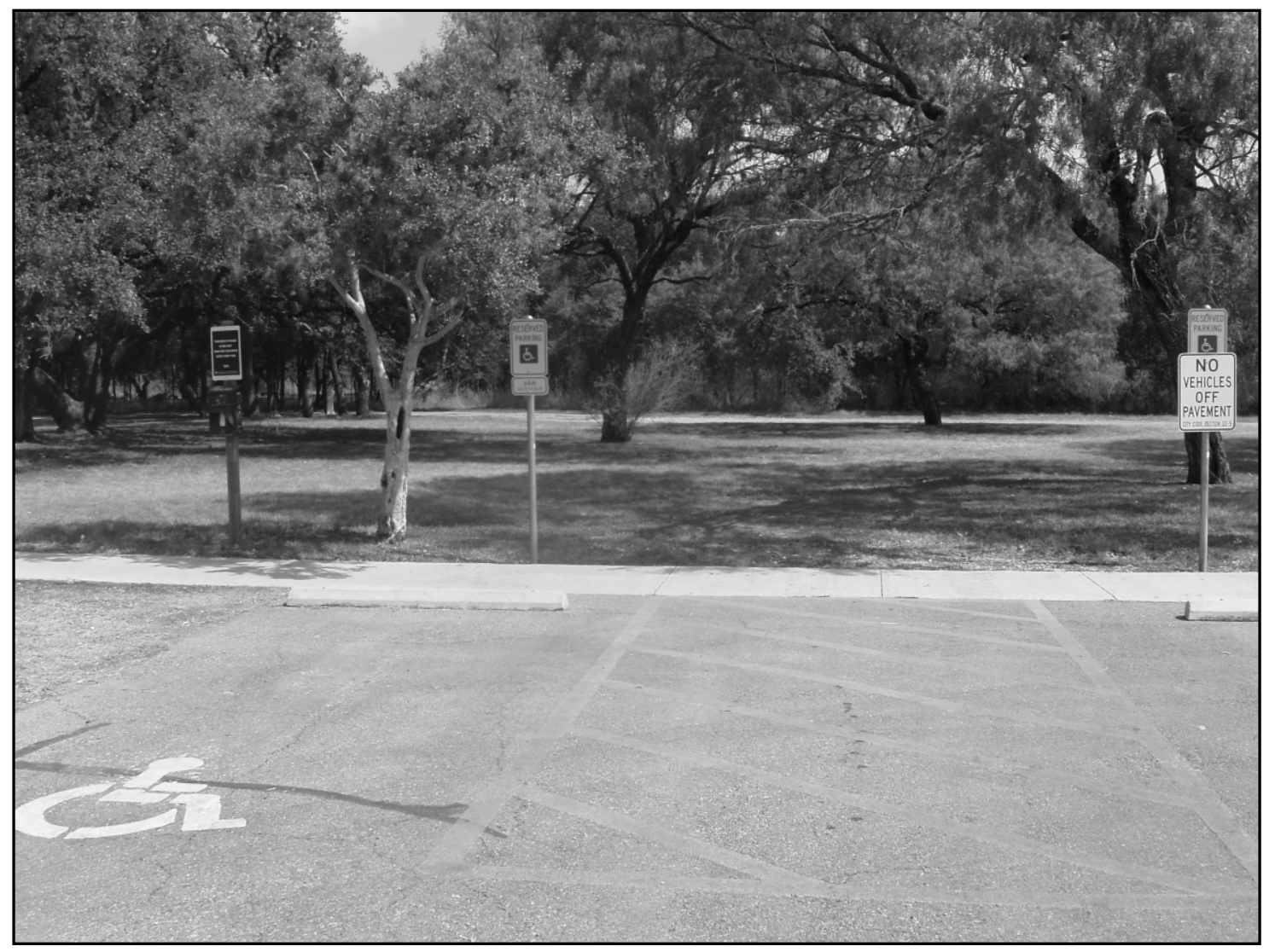

Figure 1-3. Parking lot and sidewalks in the vicinity of the new pavilion and playground in Area 1. 


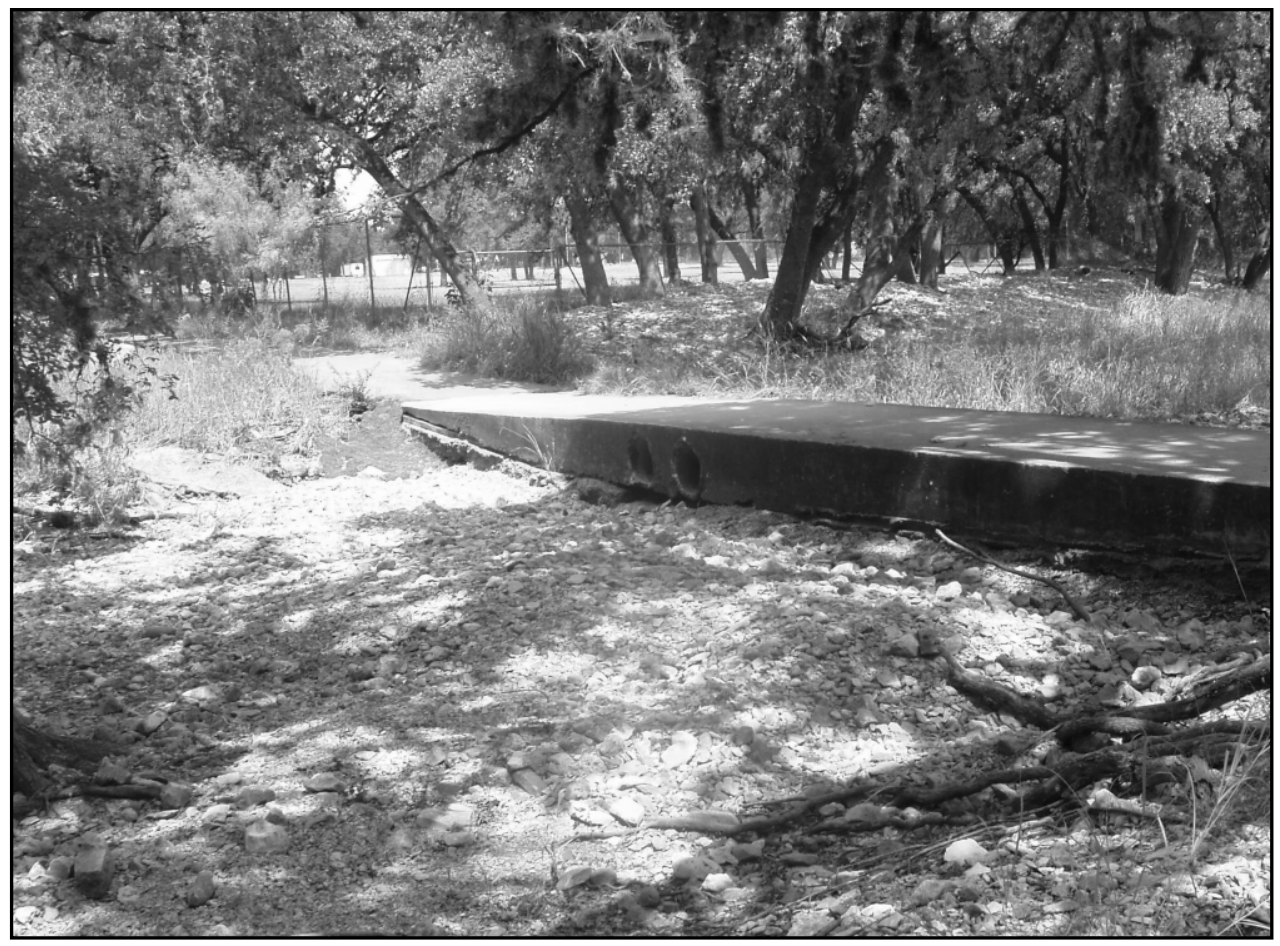

Figure 1-4. Low-water crossing in need of trail repair, Area 2.

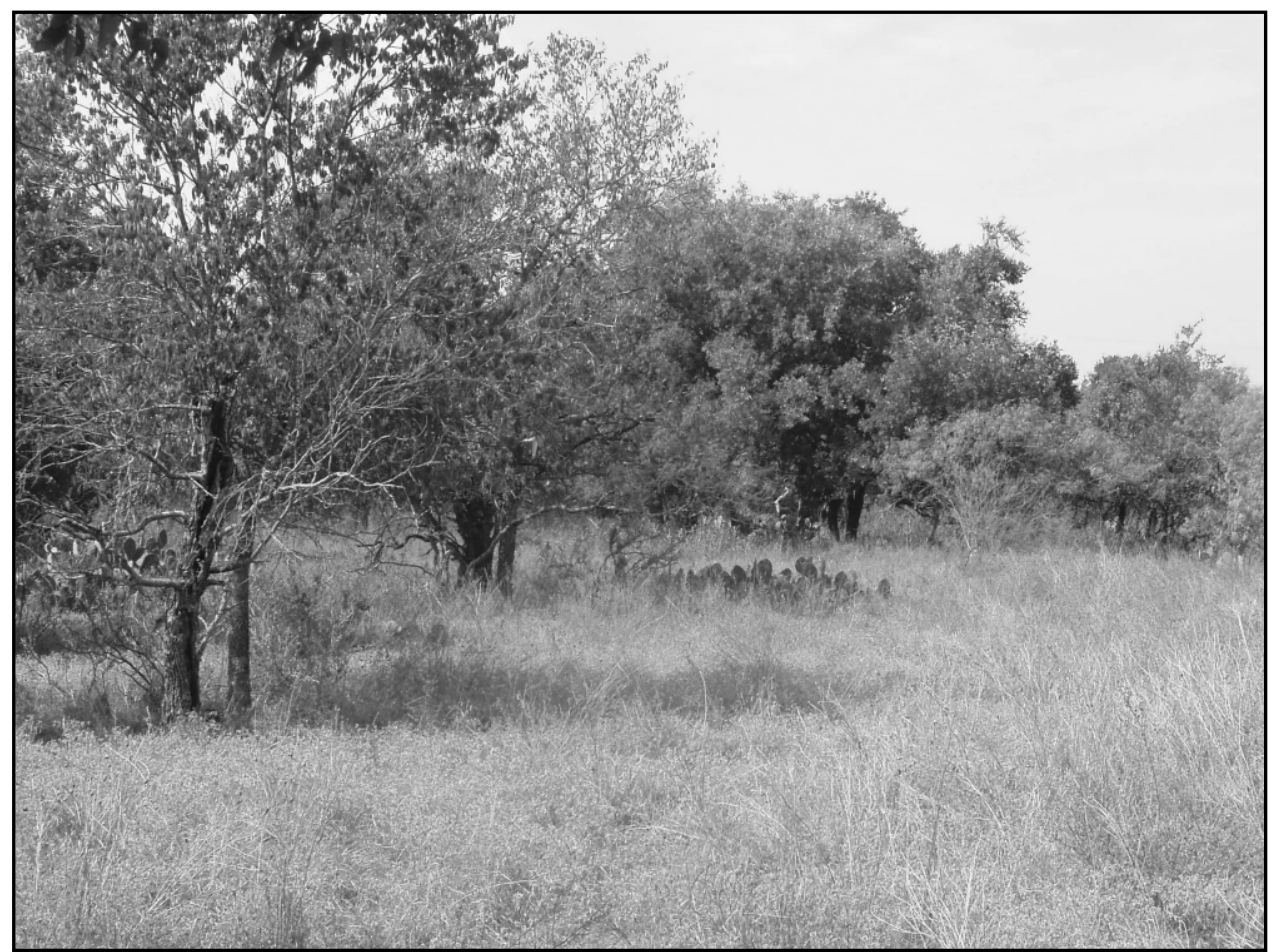

Figure 1-5. Undeveloped scrub vegetation in the area of the planned pedestrian trail, Area 3 . 


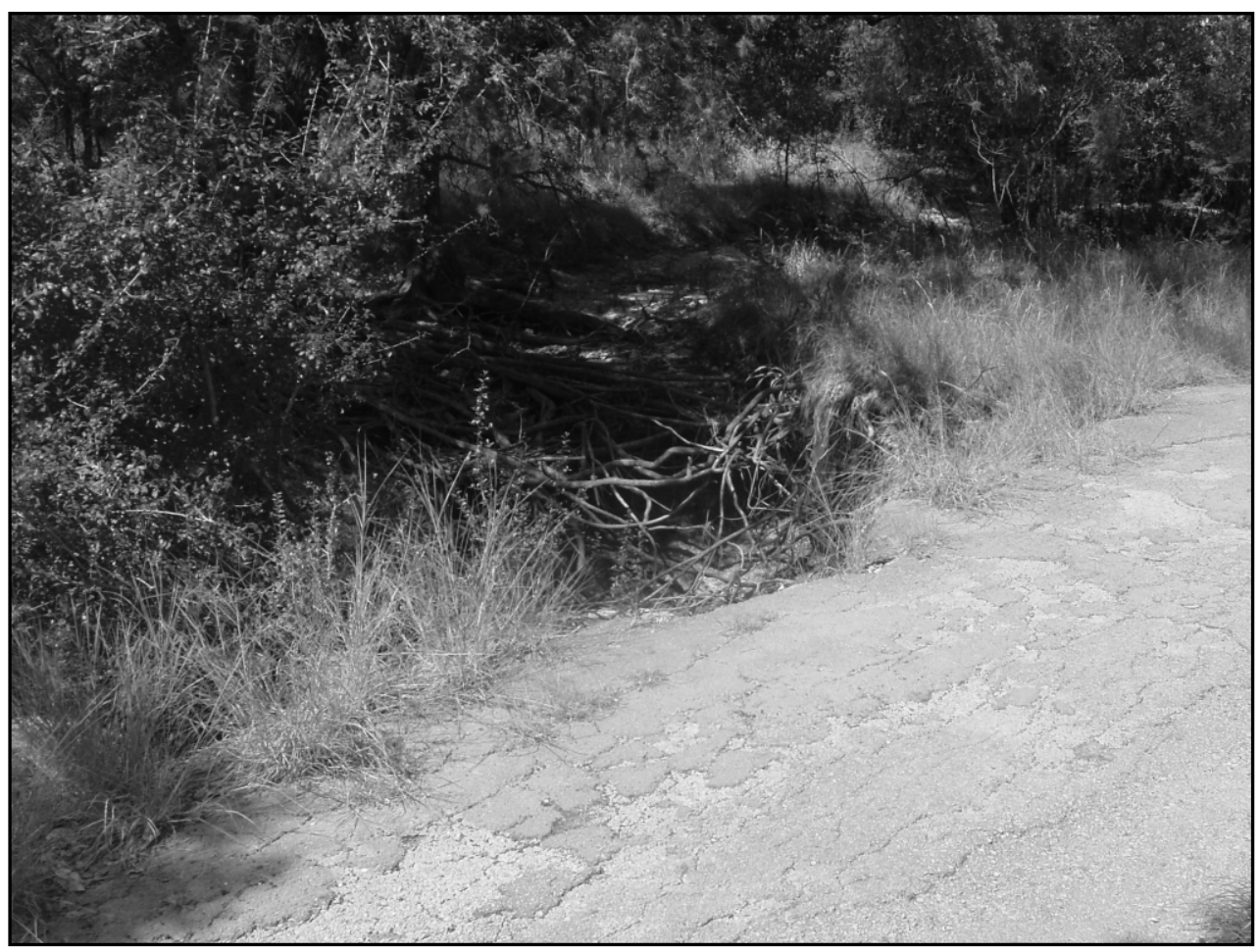

Figure 1-6. Erosion of existing trail adjacent Lorenz Creek, Area 4.

asphalt-capped and realigned to the east along a 12 -ft. wide ROW. The approximate length of proposed trail segment is $30-40 \mathrm{~m}$.

Area 5, adjacent to the Al Becker Pavilion, consists of a small gravel-surfaced parking area occasionally used to accommodate overflow parking needs (Figure 1-7). Proposed improvement to Area 5 consists of excavating 6-8 in. below surface gravel and paving over the area with asphalt.

Area 6 is located in the eastern portion of the park (the Optimist Park and Pavilion \#2 Restroom). A small plot in this area has been used as community gardens and has been fenced for a number of years. The remainder of the area is undeveloped scrub (Figure 1-8). Proposed improvements in this area of the park consist of relocating the pavilion and playground to an area just to the north. The APE measures approximately $1.25-1.5$ acres.

In Area 7 the existing trail crosses Lorenz Creek and as a result the trail is washed out (Figure 1-9). The proposed improvements to Area 7 consist of adding stone supports to the low-water trail crossing.

Area 8 is adjacent to lower Bee Tree Drive. An expansion of the existing parking lot toward the south and into the gently sloping tree-covered hill side is planned (Figure 1-10). The triangular APE is approximately $40-50 \mathrm{~m}$ in length and a maximum of $30 \mathrm{~m}$ at its widest point.

Area 9 is located in the southern portion of the park. This area covers approximately 30 acres. Approximately 50 percent of this area has been impacted by the landscape modifications which consist of the construction of an earthen berm in the northwestern portion of the area and landscouring activities in the south-central portion related to the construction of the berm (Figure 1-11). Area 10 adjoins, and is to the southeast of Area 9 (see Figure 1-2). This area is covered by mesquite, juniper and native grasses.

Area 11 is to the northeast of Area 10 along the northern and western margins of the Little League Fields (Figure 1-2). 


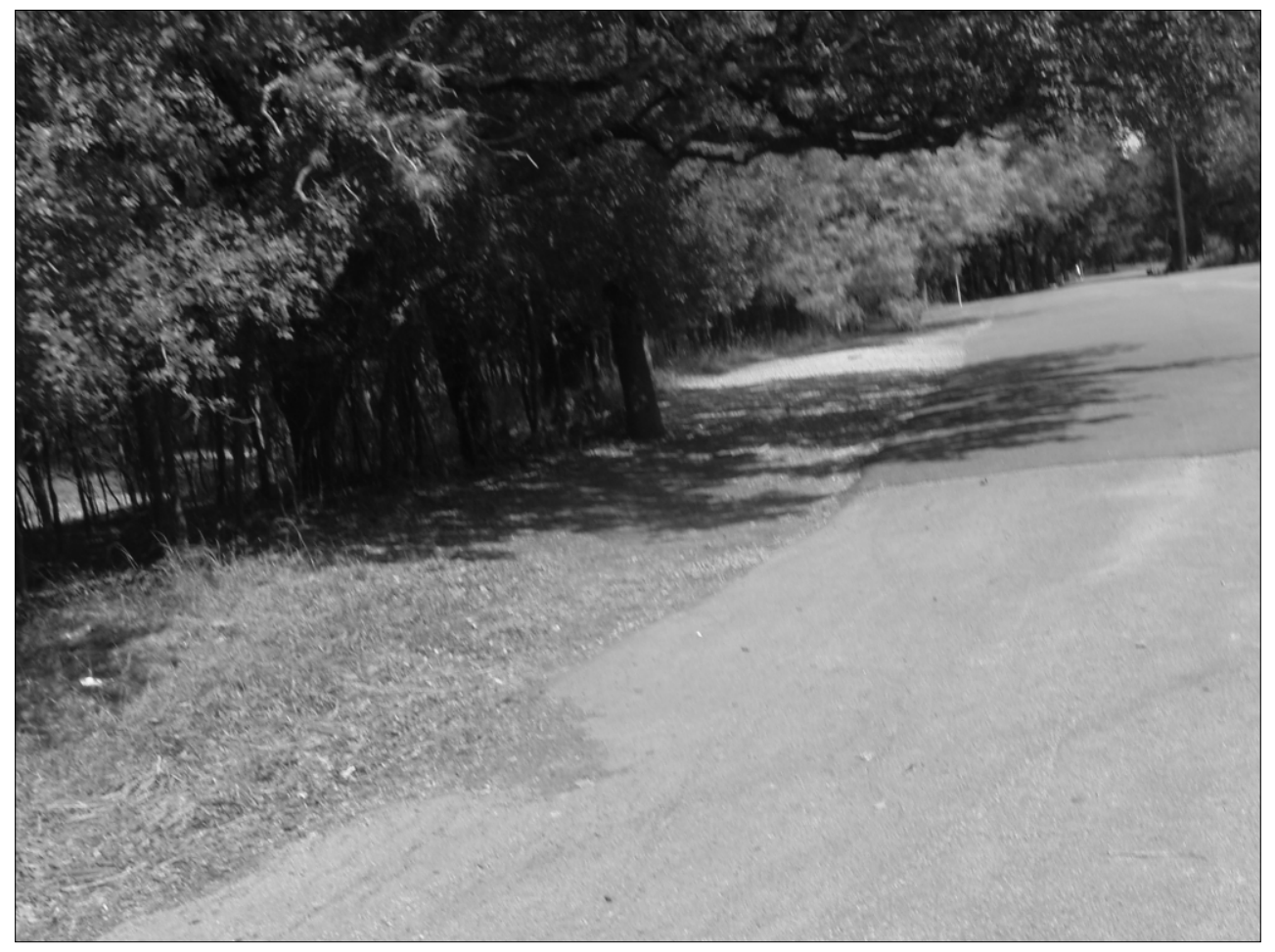

Figure 1-7. Narrow overflow parking area along existing Buckhorn Drive, Area 5.

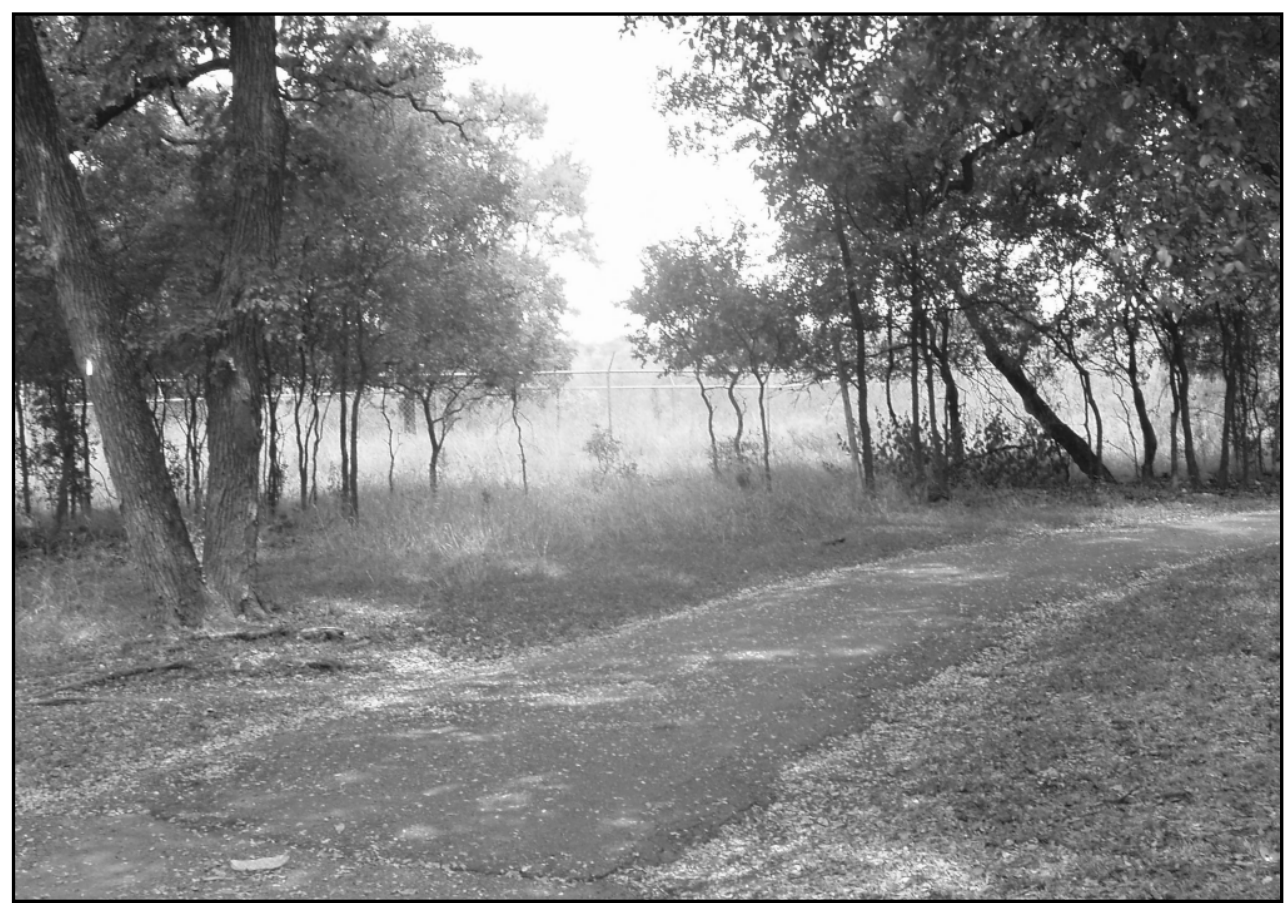

Figure 1-8. Community garden area within Area 6. The pavilion and playground will be relocated to this vicinity. 


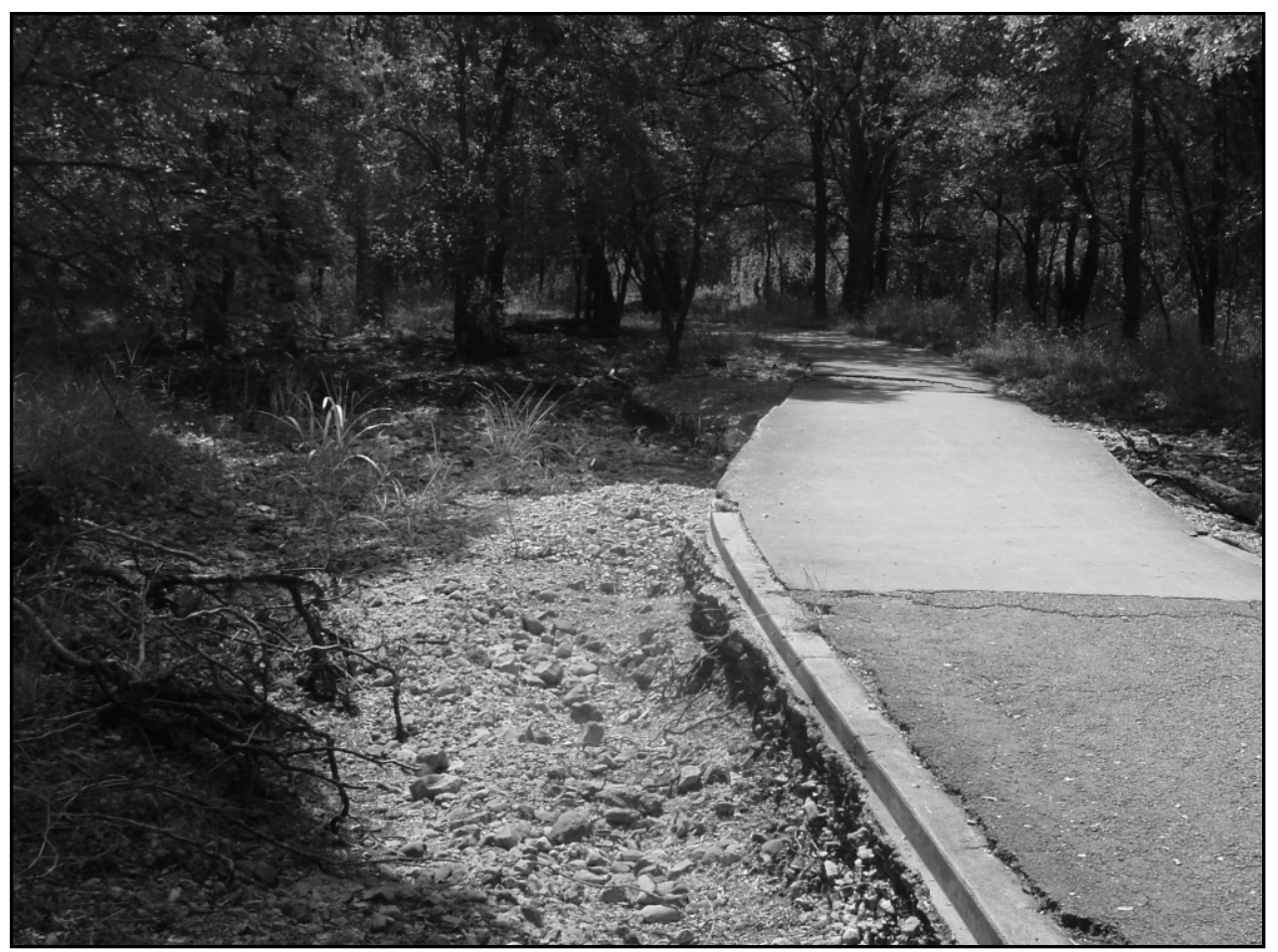

Figure 1-9. Low-water crossing of Lorenz Creek in Area 7. Note erosion at base of sidewalk.

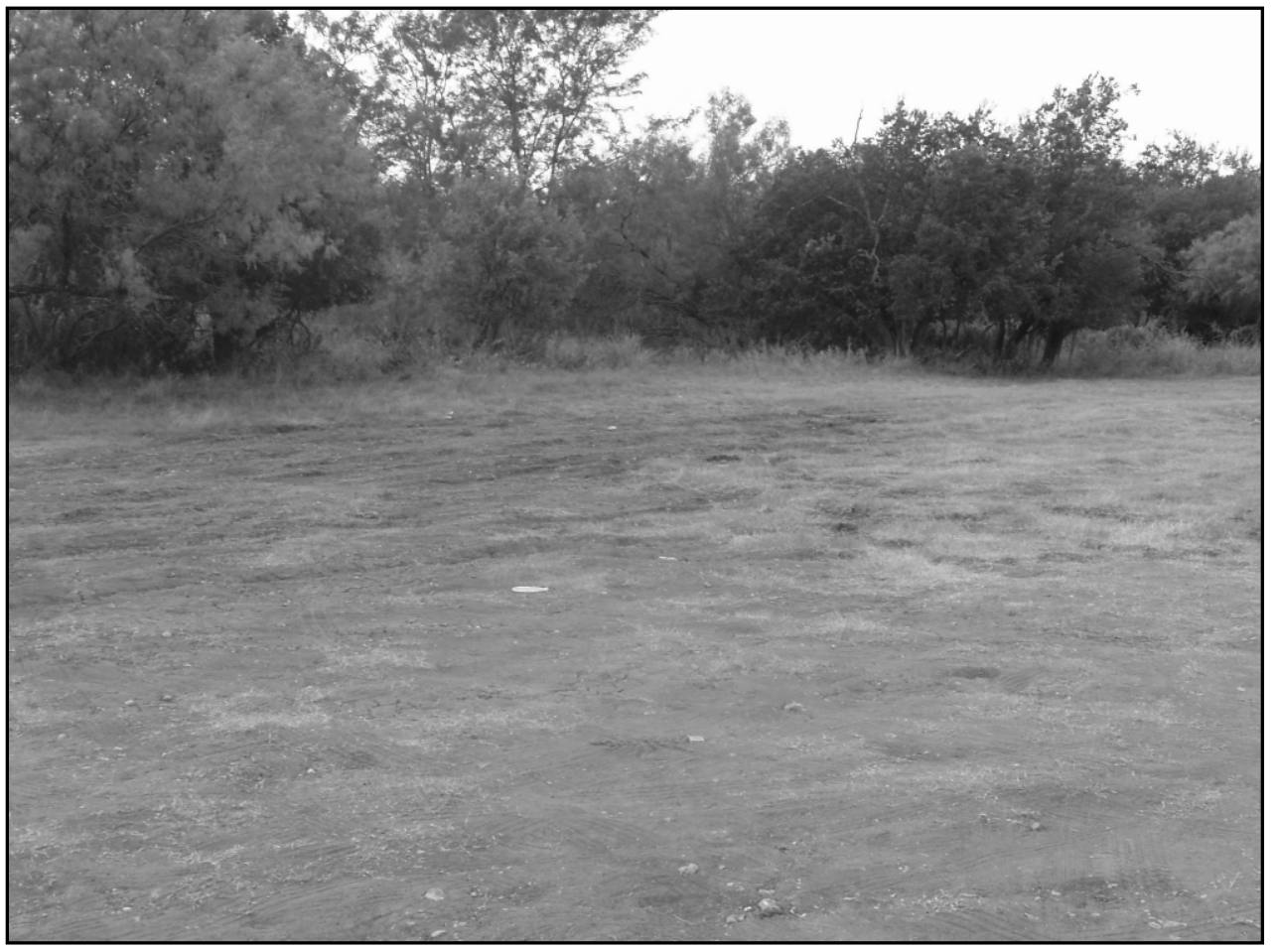

Figure 1-10. Existing dirt-covered parking lot adjacent lower Bee Tree Drive. Expansion will be into the tree-covered area in Area 8. 


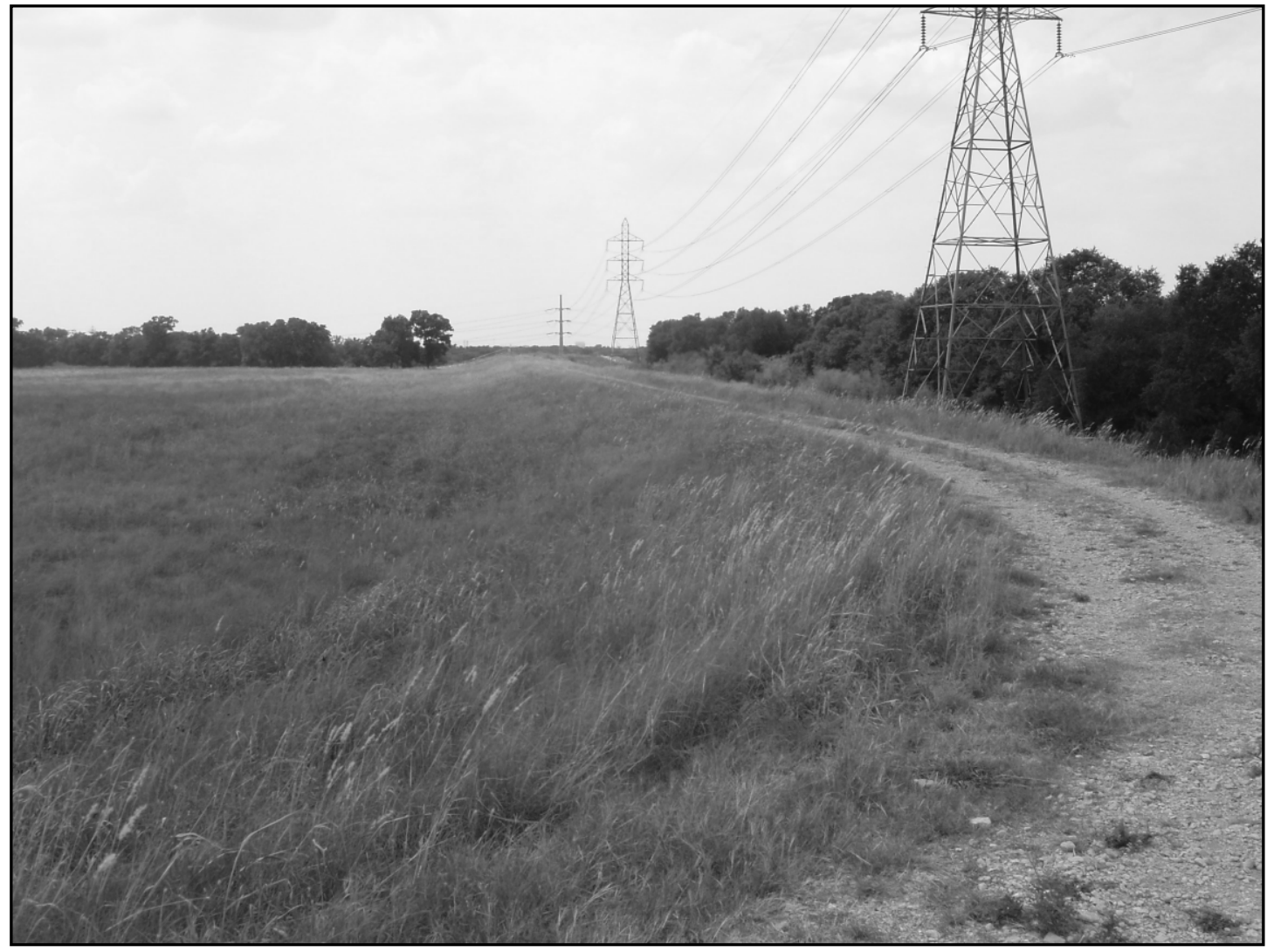

Figure 1-11. Southern portion of Area 9 showing the earthen berm.

A proposed water line will be installed along the northern edge of this area paralleling the existing power line ROW. The installation of the water line will require a 24-36-in. deep trench along a corridor that is $1,200-1,300 \mathrm{ft}$. $(360-400 \mathrm{~m})$ in length. In addition, at some future time the L-shaped area that borders the Little League Fields along their northern and western edge will be cleared and developed (Figure 1-2). This area measures approximately 30 acres.

Given that until relatively recently, the McAllister Park lands were privately owned and the families in the area owned the properties for several generations, it was thought that the collection of a brief oral history from at least one of the previous owners, Mr. Marvin Klar, would be a welcome complement to the archaeological information derived from this and several previous projects conducted within the park limits.
This and the preceding recommendations were presented in the project Scope of Work (SOW) that accompanied the Texas Antiquities Committee permit application. The project commenced after the review and acceptance of the SOW, and the receipt of the TAC Permit. 



\section{Chapter 2: Environmental Setting and Previous Archaeology}

\section{Environment and Vegetation}

McAllister Park is located in northeast Bexar County, San Antonio, Texas bounded by Wetmore Road on the east, Starcrest Road on the south, Jones-Maltsberger Road along its western edge and Thousand Oaks Road along its northern edge. The project area is depicted on the 1992 Longhorn, Texas, 7.5' USGS topographic quadrangle map. This region of Texas is within a transitional zone between two major physiographic regions: the South Texas Brush Country to the south and the Edwards Plateau to the north. These physiographic regions contain biotic zones that create a prime environment for a variety of flora and fauna. Limestone foothills that represent the Balcones Escarpment extend from northern Bexar County southwest into the area of Del Rio, on the Rio Grande River. The typical topography is represented by rugged terrain in the form of low steep hills cross-cut by several small intermittent streams. Mudd Creek and Lorenz Creek run through the project area. Mudd Creek is a tributary of Salado Creek that empties into the San Antonio River (Potter and Black 1995).

Vegetation in the area consists of typical South Texas scrub and grass species, including mesquite (Prosopis juliflora var. glandulosa), live oak (Quercus virginiana), pecan (Carya illinoinensis), Texas persimmon (Diospyros texana) and prickly pear cactus (Opuntia engelmanni; Vines 1960). Soils in this area consist of Lewisville silty clays that are a dark grayish-brown in color and develop under grassy vegetation on well-drained nearly level to gently sloping terraces above floodplains (Taylor et al. 1966:113).

\section{Previous Archaeological Investigations in McAllister Park}

The cultural resources present in Bexar County range from prehistoric to historic time periods. Archaeology in the area has revealed remains from the following cultural periods: Paleoindian (ca. 11000-8000 BP), Archaic (ca. 8000-1150 BP), and Late Prehistoric (ca. 1150-350 BP) through the Historic period (Hester 1995). As a result of various archaeological surveys along tributaries and watersheds in the area, several sites have been recorded within the park boundaries.
In 1972, Anne Fox, under the direction of the Texas Archaeological Salvage Project, conducted a pedestrian survey, with the permission of the City of San Antonio Parks and Recreation Department, within the McAllister Park boundaries to determine the presence of any archaeological sites (Fox 1973). Three sites were recorded: 41BX172, 41BX173 and 41BX174. Site 41BX172 was a Late Archaic campsite that is along Bee Tree Drive. The site was approximately $200 \mathrm{ft}$. in diameter with shallow deposits. Cultural material present at the site included burned rock, lithic debitage and tools. Site 41BX173, also situated along Bee Tree Drive, was approximately $200-\mathrm{x}-250 \mathrm{ft}$. with the presence of lithic debitage and tools. 41BX174 was recorded east of the Buckhorn and Bee Tree Drive intersection and occupied the entire top of the hill. This Archaic to Late Prehistoric site consisted of lithic debitage and cores that were visible on the surface (Fox 1973:3-5).

In 1974, CAR conducted investigations for several proposed floodwater-retarding structures along Salado Creek (Hester et al. 1974). As a result of these investigations, 29 archaeological sites were identified and 41BX458 was documented at this time. The site is east of Mudd Creek and within the park boundaries. The site measured approximately $75-\mathrm{x}-30 \mathrm{~m}$ in size. Cultural material at the site included chert cobbles and lithic debitage. No further work was recommended on the site.

During 1976 and 1977 Anne Fox conducted the archaeological survey and assessment of 11 different drainages and three sewage treatment plant areas around San Antonio for the preparation of an Environmental Impact Statement for the San Antonio 201 Wastewater Treatment Facilities Project (Fox 1977). As a result of this survey numerous sites were identified throughout San Antonio. Sites 41BX353 and 41BX354 were identified from these efforts and are located along Mudd Creek. 41BX353 is on the west bank of Mudd Creek within McAllister Park, located to the west of the park road. The site is approximately $20-\mathrm{x}-10 \mathrm{~m}$ in size and at the time it was intersected by a dirt road. The site was thought to be a camp site with abundant lithic debitage. No further work was recommended on the site. 41BX354 is located off the park grounds, just north of Thousand Oaks Road. This site reportedly had a high density of lithics along with a burned rock midden (650-x-200 m). 
There appeared to be plowing and bulldozing disturbance to the site. Further investigations were recommended on the site.

Sites 41BX1410, 41BX1411 and 41BX1412 were recorded in 1999 by CAR (Tomka and Robinson 2000) when an intensive pedestrian survey and subsurface testing was conducted along the proposed extensions to the McAllister Park road system. 41BX1410 covers an area that is approximately $162 \mathrm{~m}^{2}$. Cultural material retrieved from the site suggested an ephemeral occupation and no further work was recommended. Soils on this site were shallow, only reaching a maximum depth of 15 centimeters below surface (cmbs). 41BX1411 is about $130 \mathrm{~m}^{2}$ in size and consisted of a surface scatter of flakes, cores and one biface. Due to the shallowness of the site $(20 \mathrm{cmbs})$ no further work was recommended. 41BX1412 is located on the south bank of Mudd Creek and is bisected by Bee Tree Drive. It was a multi-component site containing Historic, Middle Archaic, Early Archaic and a possible Paleoindian component. Cultural material recovered from the site consisted of Guadalupe adzes, a Uvalde projectile point and other lithic tools. No intact deposits were identified during the data recovery efforts in 2000, and researchers concluded that the deposits were disturbed (Tomka 2002).

Additionally, in 1999 CAR conducted intensive survey and shovel testing of a proposed parking lot and two proposed roadway spur extensions adjacent to existing soccer fields (Zapata 2002). No prehistoric or historic sites were identified during the survey. No further work was recommended and proposed improvements at McAllister Park proceeded as planned.

Site 41BX959 is located along the east bank of Mudd Creek. When the site was originally recorded in 1991 by C. K. Chandler, it consisted of tested cobbles, burned rock, lithic debitage and tools. Much of the area had been cleared of vegetation (Texas Historical Commission [THC] 2005). The site was revisited and shovel tested in 2005 by CAR as part of a project for the San Antonio International Airport (Figueroa and Thompson 2005). Soon after the archaeological survey commenced the property that the site occupies was eliminated from the project area. It has been heavily disturbed by landscape modifications and clearing. The 2005 Airport Survey not only revealed the site to be much larger than originally recorded, but it also revealed a historic component. Along with the historic artifacts recovered (ceramics and glass) the remnants of a building that appears on the 1953 Longhorn, TX 7.5' USGS quadrangle map of the area were also identified. Cultural material scattered on the surface of the site and recovered from the upper deposits of shovel tests included cores, bifaces and hammerstone flakes. Due to the extensive disturbance of the deposits and the lack of features the site did not warrant formal designation as a State Archeological Landmark and was not recommended as eligible for nomination to the National Register of Historic Places. A portion of this site extends into the southwest corner of Area 9. 


\section{Chapter 3: Field and Laboratory Methods}

The Parks and Recreation Department contracted the Center for Archaeological Research to conduct a 100 percent pedestrian survey of the Areas of Potential Effect (APE). The pedestrian survey had one principal goal: Identify and document all prehistoric and/or historic archaeological sites that may be impacted by the proposed improvements within the specific APEs. There were a total of eleven Areas of Potential Effect that lie within the McAllister Park Improvements and the construction of Regional Youth Sports Practice Fields (Figure 1-2).

In two of the APEs (Areas 2 and 7), the improvements were to consist only of repairs to existing trails at low-water crossings. Because adjacent banks were not going to be impacted by the improvements and repair CAR recommended no archaeological investigations in the vicinity. In one additional APE (Area 5), the planned improvements were going to impact an existing temporary parking area. Given that this narrow strip had been previously disturbed and construction was not going to impact below the disturbed zone, CAR again recommended no investigations in the area. A 100 percent pedestrian survey was conducted in the remaining eight areas $(1,3,4,6,8,9,10$ and 11).

In the Scope of Work CAR recommended pedestrian survey and shovel testing efforts in these remaining areas. To inspect the area that was to be impacted by the new pavilion and playground, we recommended the excavation of three to four shovel tests. In Area 3, where new asphalt was to be constructed, we recommended the excavation of five to six shovel tests at roughly $30 \mathrm{~m}$ apart along the proposed ROW. In Area 4, where the existing trail was being realigned, we proposed the excavation of two to three shovel tests along the ROW at a distance of 10-15 $\mathrm{m}$ from each other. In the 1.25-1.5 acre APE impacted by the relocation of a pavilion and playground (Area 6), CAR proposed the excavation of three to four shovel tests during the systematic pedestrian survey of the area. The proposed improvements in Area 8 consisted of expanding an existing parking area to the southeast into a tree-covered slope. CAR proposed to excavate three to four shovel tests approximately $10-15 \mathrm{~m}$ apart within the APE, approximately $9 \mathrm{~m}(30 \mathrm{ft}$.) from the edge of the current parking lot.
The proposed improvements in Area 9 consist of the construction of practice fields within an area covering approximately 30 acres. Since roughly 50 percent of the area has been extensively disturbed, CAR proposed the survey and shovel testing of only 15 acres of Area 9. In addition, previous survey of the area was conducted in the spring of 2005 by CAR as part of the San Antonio International Airport Expansion Project Survey (Figueroa and Thompson 2005). Five shovel tests were excavated in the northeastern portion of the area during the spring 2005 survey. Site 41BX959 is located on the southwestern portion of the area and was revisited by CAR in 2005. Considering that a majority of the area was surveyed during the spring of 2005 the excavation of only five to six additional shovel tests was planned in this area.

In the approximately 3-acre area where a dog park is to be established (Area 10) adjoining Area 9, CAR proposed the excavation of six shovel tests during the systematic survey. Finally, in the 30-acre L-shaped Area 11, CAR proposed the excavation of seven shovel tests. These were in addition to the six to seven shovel tests (spaced approximately $60 \mathrm{~m}$ apart) proposed along the waterline trench that was to be excavated along the northern edge of the area.

During the pedestrian survey, surface inspection was conducted while crewmembers traversed the areas along transects spaced at a maximum of $30 \mathrm{~m}$ apart. The number of shovel tests proposed for each area was determined according to THC standards for linear and aerial surveys.

The shovel testing entailed systematic excavation of small circular pits measuring $30 \mathrm{~cm}$ in diameter. Each shovel test reached a maximum depth no greater than $60 \mathrm{cmbs}$, unless otherwise prevented by obstructions. The crew excavated shovel tests in controlled levels not exceeding $10 \mathrm{~cm}$ in thickness in order to record accurate observations of depth of any artifacts encountered. Deposits from these tests were screened through 1/4-in. mesh. All artifacts found in the shovel tests were collected and bagged by provenience and returned to the CAR laboratory for processing and analysis. 
CAR staff used standardized forms to note any artifacts recovered and collected from shovel tests. A shovel test form was completed for every excavated shovel test even if no artifacts were recovered. Observations were also made about the nature of the deposits seen in each test and the final excavation depth. Finally, descriptions of the cultural materials recovered were listed and brief soil descriptions (texture, consistency, color, inclusions) were completed. Surveyors recorded all shovel test locations using a Trimble Geo Explorer II Global Positioning System (GPS) unit.

If crewmembers encountered evidence of cultural activity in a shovel test or observed a concentration of artifacts on the surface, additional shovel tests were excavated at a reduced interval along the transect or in the four cardinal directions at $15-\mathrm{m}$ intervals from the positive unit to define the extent of the distribution. For the purpose of this survey, a site was defined only when a location contained either (1) five or more surface artifacts within a $15-\mathrm{m}$ radius (ca. 706.9- $\mathrm{m}^{2}$ ), (2) a single cultural feature, such as a hearth, either on surface or exposed in shovel testing, (3) a positive shovel test containing at least three artifacts within a given 10-cm level, (4) a positive shovel test containing at least five total artifacts, or (5) two positive shovel tests located within $30 \mathrm{~m}$ of each other.

When artifacts did not constitute a site as defined above, they were classified as isolated finds. In all cases, observations about isolated finds were recorded on separate forms prepared for this project and their location was determined with GPS receivers. We did not collect artifacts constituting isolated finds unless they were temporally diagnostic.

\section{Archaeological Laboratory Methods}

All cultural materials and records obtained and/or generated during the project were prepared in accordance with federal regulation 36 CFR part 79, and THC requirements for State Held-in-Trust collections. The few artifacts recovered during the project were processed in the CAR laboratory. They were washed, air-dried, and stored in 4-mm zip locking archival-quality bags. Acid-free labels were placed in all artifact bags. Each label contained provenience information and a corresponding lot number laser printed or written with pencil. Artifacts were labeled with permanent ink over a clear coat of acrylic and covered by another acrylic coat. Artifacts were separated by class and stored in acid-free boxes identified with standard tags. Field notes, forms, photographs, and drawings were placed in labeled archival folders. Photographs, slides, and negatives were labeled with archival materials and placed in archival-quality sleeves. Any soiled forms were placed in archival-quality page protectors. Maps and illustrations produced were placed in archival-quality page protectors. A copy of the survey report and all computer disks pertaining to the investigations were curated with the field notes and documents.

Individual categories of artifacts were then analyzed by specific attributes designated for each class. All data was entered into an Excel spreadsheet. Upon completion of the project, all artifacts and documentation pertaining to the project were curated at the CAR facility. 


\section{Chapter 4: Results of Field Investigations and Oral History Interview}

\section{Results of Field Investigations}

Between September 19 and 22, 2005 a 100 percent pedestrian survey was conducted within the confines of McAllister Park by the Center for Archaeological Research. The survey was conducted in advance of proposed improvements to eleven Areas of Potential Effect within the park boundaries. In eight of the proposed APEs (Areas 1, 3, 4, 6, 8, 9, 10, and 11), impacts were to occur in areas that could contain intact cultural deposits. In the remaining three areas $(2,5$ and 7$)$ the improvement impacts were to be localized within the active channel of a creek (Areas 2 and 7) or within a previously disturbed area (Area 5). While in the latter three areas CAR recommended no archaeological investigations, the CAR staff conducted a 100 percent pedestrian survey of all remaining eight areas. The pedestrian survey consisted of surface inspection and subsurface investigations though shovel testing. As a result of the pedestrian survey a total of 45 shovel tests were excavated (Table 4-1) and approximately 62 acres were traversed. No sites were identified during the survey, though two isolated finds were recorded.

Area 1 (Figure 4-1) is located in the northern portion of the park, adjacent to Turkey Roost Drive. Proposed improvements in this area consist of a new playground and pavilion. This area was maintained and clear of vegetation. Ground visibility was very good in the area, ranging between 80 and 90 percent. Four shovel tests were excavated in this area (ST 1-4). Soils in Shovel Tests 1 through 3 consisted of dark brown silty loam that was very compact. The first $10 \mathrm{~cm}$ of Shovel Test 4 contained brown loam while the matrix in the remaining levels was made up of gravel fill (Figure 4-2). The only cultural material encountered in Area 4 was a piece of lithic debitage that was recovered from Shovel Test 3, Level $2(10-20 \mathrm{cmbs})$. Since the shovel test to the northeast of Shovel Test 3 was negative and walkways and trails limited placing shovel tests to the west and north, the cultural material encountered in Area 1 was defined as an isolated find (Table 4-2).

Area 3 (Figure 4-3) is located east of Buckhorn Drive, near the Jones-Maltsberger entrance to the park. The proposed improvements in this area will consist of the construction of a pedestrian asphalt trail linking Buckhorn Drive to the new
Table 4-1: Terminal Depths of Shovel Tests

\begin{tabular}{|c|c|c|c|}
\hline Area & Shovel Test\# & Max. Depth (cmbs) & Disturbance \\
\hline 1 & 1 & 60 & max.depth \\
\hline 1 & 2 & 50 & \begin{tabular}{|l} 
gravels \\
\end{tabular} \\
\hline 1 & 3 & 40 & gravels \\
\hline 1 & 4 & 50 & \begin{tabular}{|l|} 
gravel fill \\
\end{tabular} \\
\hline 3 & 42 & 60 & max.depth \\
\hline 3 & 43 & 60 & max.depth \\
\hline 3 & 44 & 28 & bedrock \\
\hline 3 & 45 & 60 & max.depth \\
\hline 4 & 18 & 60 & max.depth \\
\hline 4 & 19 & 60 & \begin{tabular}{|l|} 
max.depth \\
\end{tabular} \\
\hline 4 & 20 & 26 & natural gravels \\
\hline 6 & 37 & 50 & natural gravels \\
\hline 6 & 38 & 60 & max.depth \\
\hline 6 & 39 & 60 & max.depth \\
\hline 6 & 40 & 60 & \begin{tabular}{|l|} 
max.depth \\
\end{tabular} \\
\hline 6 & 41 & 60 & max.depth \\
\hline 8 & 34 & 40 & natural gravels \\
\hline 8 & 35 & 40 & natural gravels \\
\hline 8 & 36 & 50 & natural gravels \\
\hline 9 & 5 & 60 & max.depth \\
\hline 9 & 6 & 20 & natural gravels \\
\hline 9 & 7 & 60 & max.depth \\
\hline 9 & 8 & 20 & max.depth \\
\hline 9 & 9 & 50 & natural gravels \\
\hline 10 & 10 & 10 & asphalt/fill \\
\hline 10 & 11 & 5 & asphalt/fill \\
\hline 10 & 12 & 10 & \begin{tabular}{|l|} 
gravel fill \\
\end{tabular} \\
\hline 10 & 13 & 10 & \begin{tabular}{|l|} 
gravel fill \\
\end{tabular} \\
\hline 10 & 14 & 20 & asphalt/fill \\
\hline 10 & 15 & 10 & \begin{tabular}{|l|} 
gravel fill \\
\end{tabular} \\
\hline 10 & 16 & 60 & max.depth \\
\hline 11 & 21 & 60 & max.depth \\
\hline 11 & 22 & 60 & max.depth \\
\hline 11 & 23 & 60 & max.depth \\
\hline 11 & 24 & 60 & max.depth \\
\hline 11 & 25 & 60 & max.depth \\
\hline 11 & 26 & 30 & natural gravels \\
\hline 11 & 27 & 60 & max.depth \\
\hline 11 & 28 & 60 & max.depth \\
\hline 11 & 29 & 40 & natural gravels \\
\hline 11 & 30 & 30 & natural cobbles \\
\hline 11 & 31 & 60 & max.depth \\
\hline 11 & 32 & 60 & \begin{tabular}{|l|} 
max.depth \\
\end{tabular} \\
\hline 11 & 33 & 60 & max.depth \\
\hline
\end{tabular}




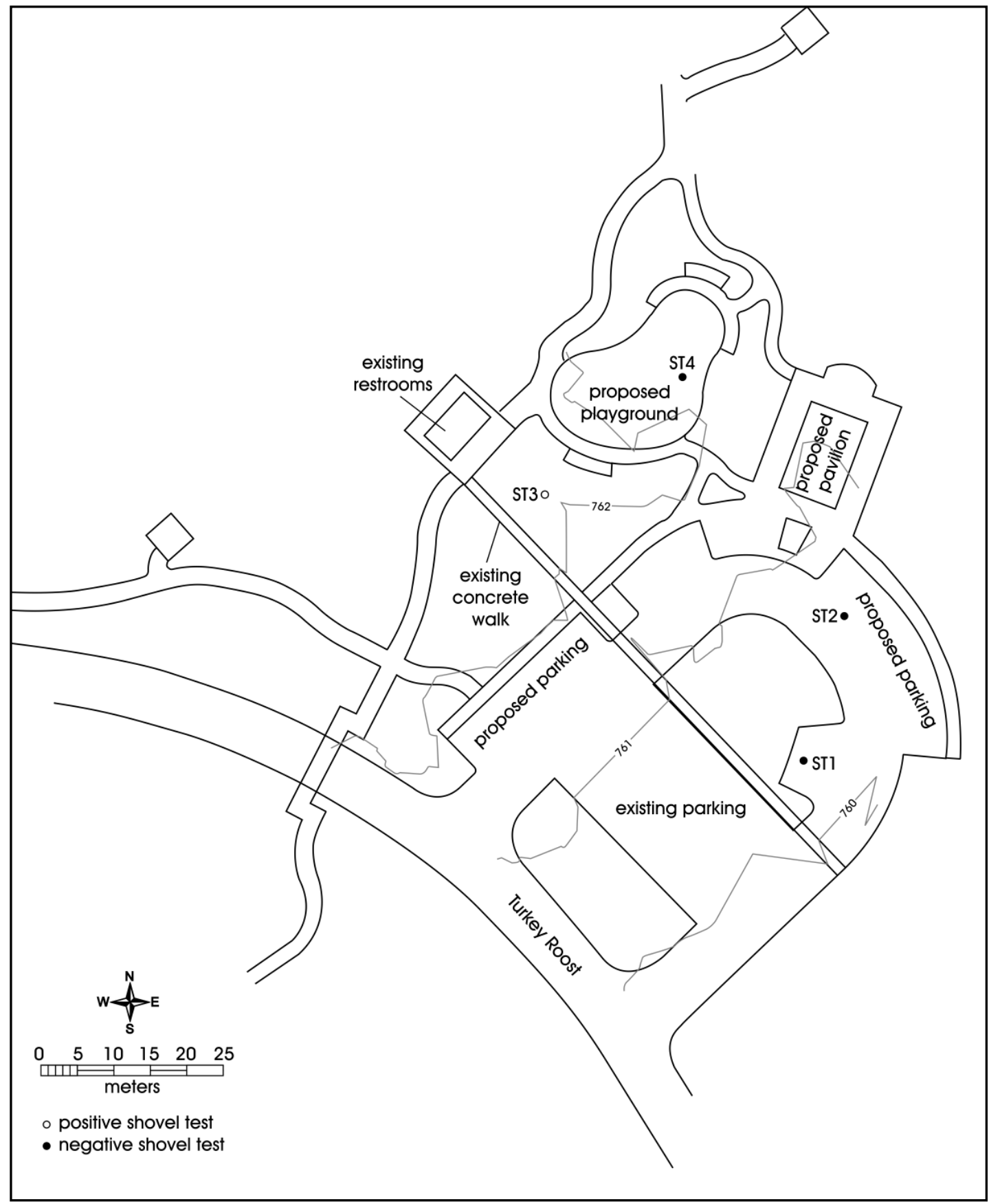

Figure 4-1. Map showing shovel tests in Area 1. 
pavilion and playground. The area was sparsely vegetated with prickly pear and persimmon and ground surface visibility was 40 to 50 percent. A total of four shovel tests were excavated in this area (ST 42-45). Though five to six shovel tests were initially proposed for this area, the presence of a bee hive at the northwestern end of the proposed trail corridor made for unsafe working conditions and the placement of a fifth shovel test was not attempted. Three of the four shovel tests reached a depth of $60 \mathrm{cmbs}$ (Table 4-1). Soils encountered in those two shovel tests consisted of dark brown silty clay and an absence of cultural material. Shovel Tests 42 and 43, on the southeastern portion of the proposed trail, contained of large cobbles. Shovel Test 44 encountered eroding bedrock at $28 \mathrm{cmbs}$ (Figure 4-4).

Area 4 is located just off Buckhorn Drive in the northwestern portion of the park (Figure 1-2). Proposed improvements in this area consist of realigning a portion of the existing trail away from the creek channel (Figure 4-5). The existing trail runs along Lorenz Creek and is eroding (Figure 1-6). The proposed new trail winds though oaks and underbrush (Figure 4-6). Vegetation in the area is sparse to moderate with an abundance of live oak and prickly pear. A total of three shovel tests (ST 18-20) were excavated in this area.

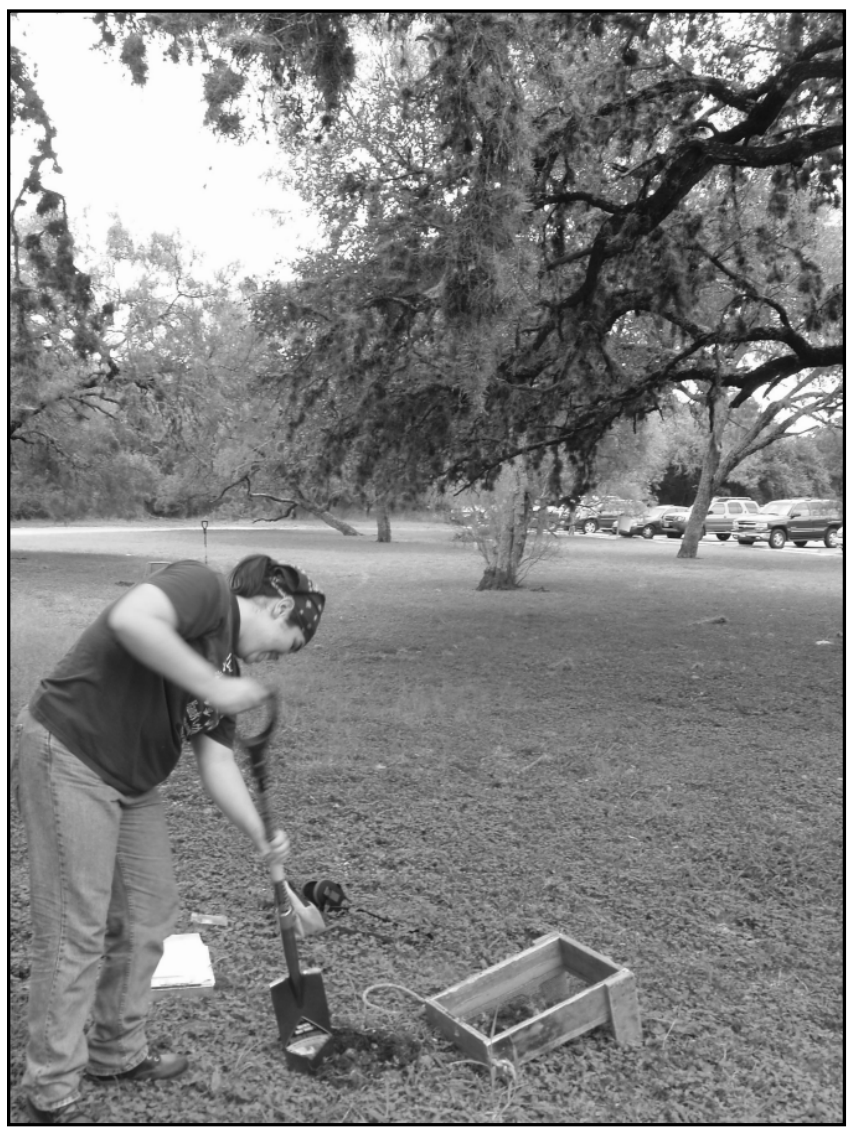

Figure 4-2. Shovel Test 4 being excavated in Area 1.

Table 4-2: Isolated Artifact Finds

\begin{tabular}{|c|c|c|c|}
\hline Area & Shovel Test\# & Depth (cmbs) & Artifact \\
\hline 1 & 3 & $10-20$ & debitage \\
\hline 6 & 39 & $10-20$ & debitage \\
\hline
\end{tabular}




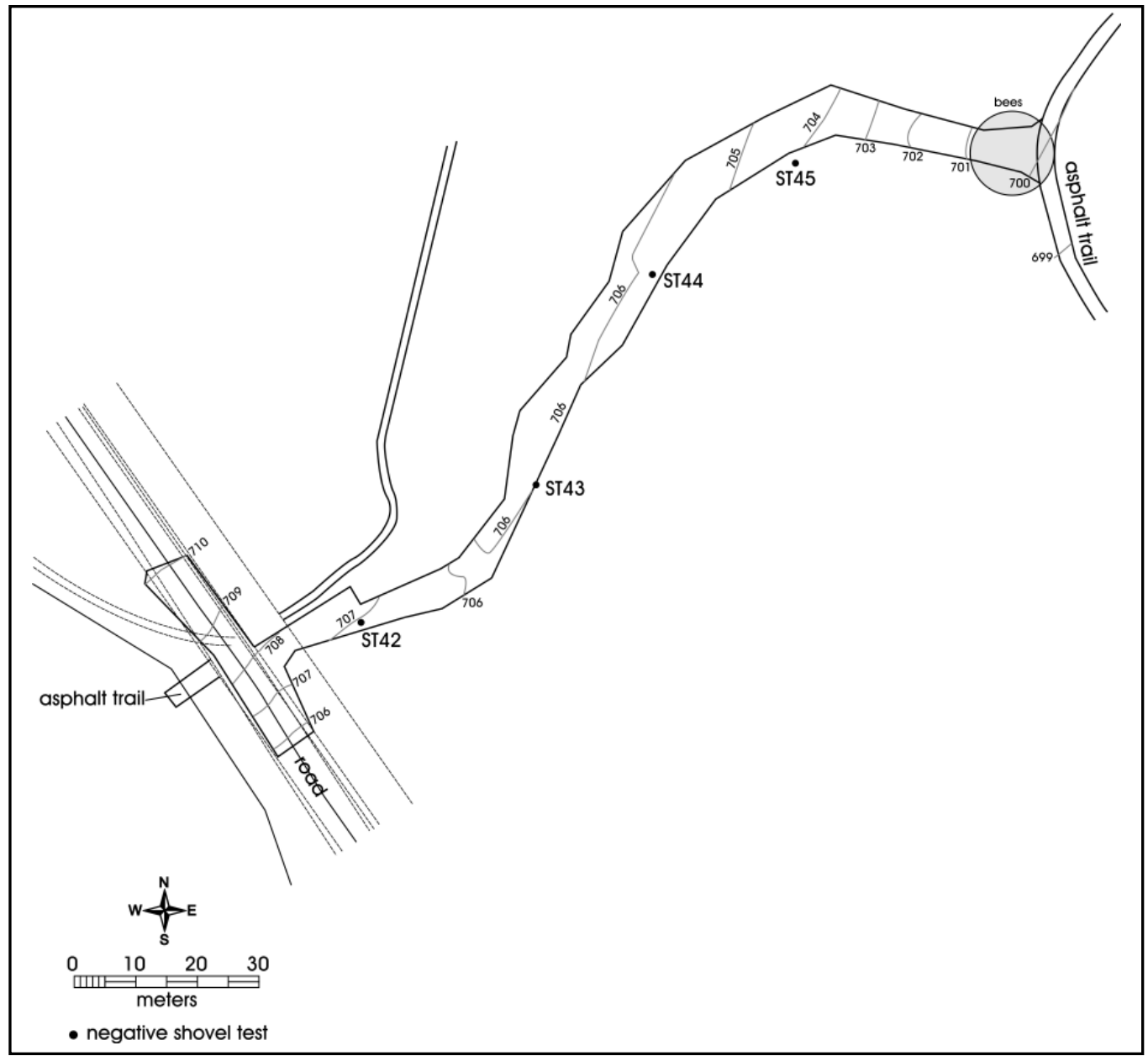

Figure 4-3. Map showing shovel tests in Area 3.

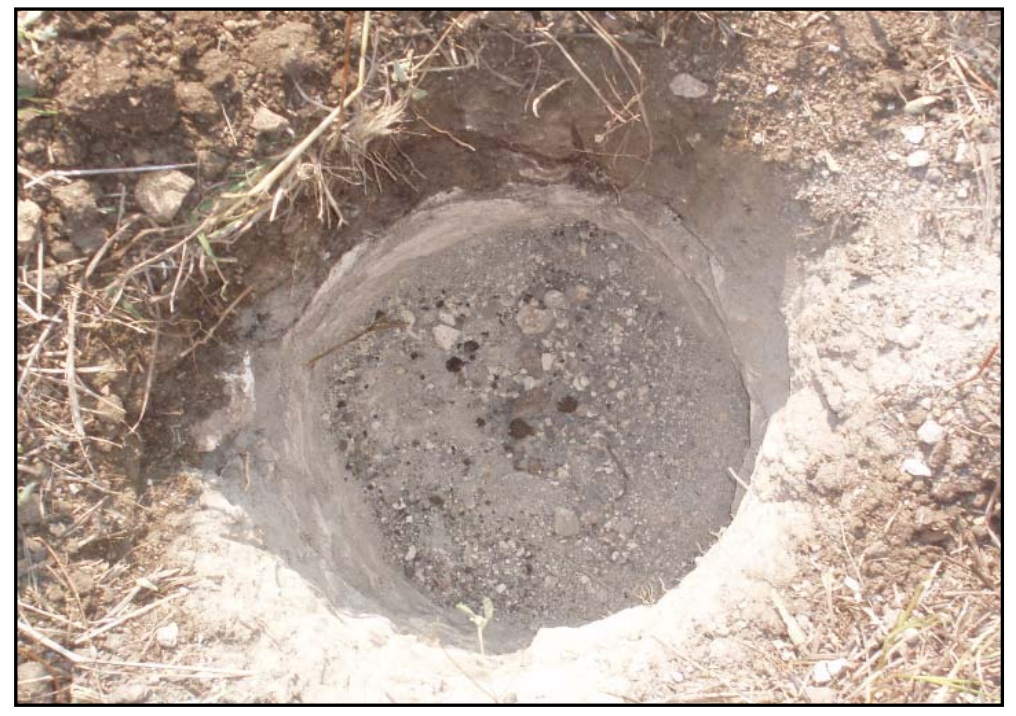

Figure 4-4. Bedrock that was encountered in Shovel Test 44 in Area 3. 


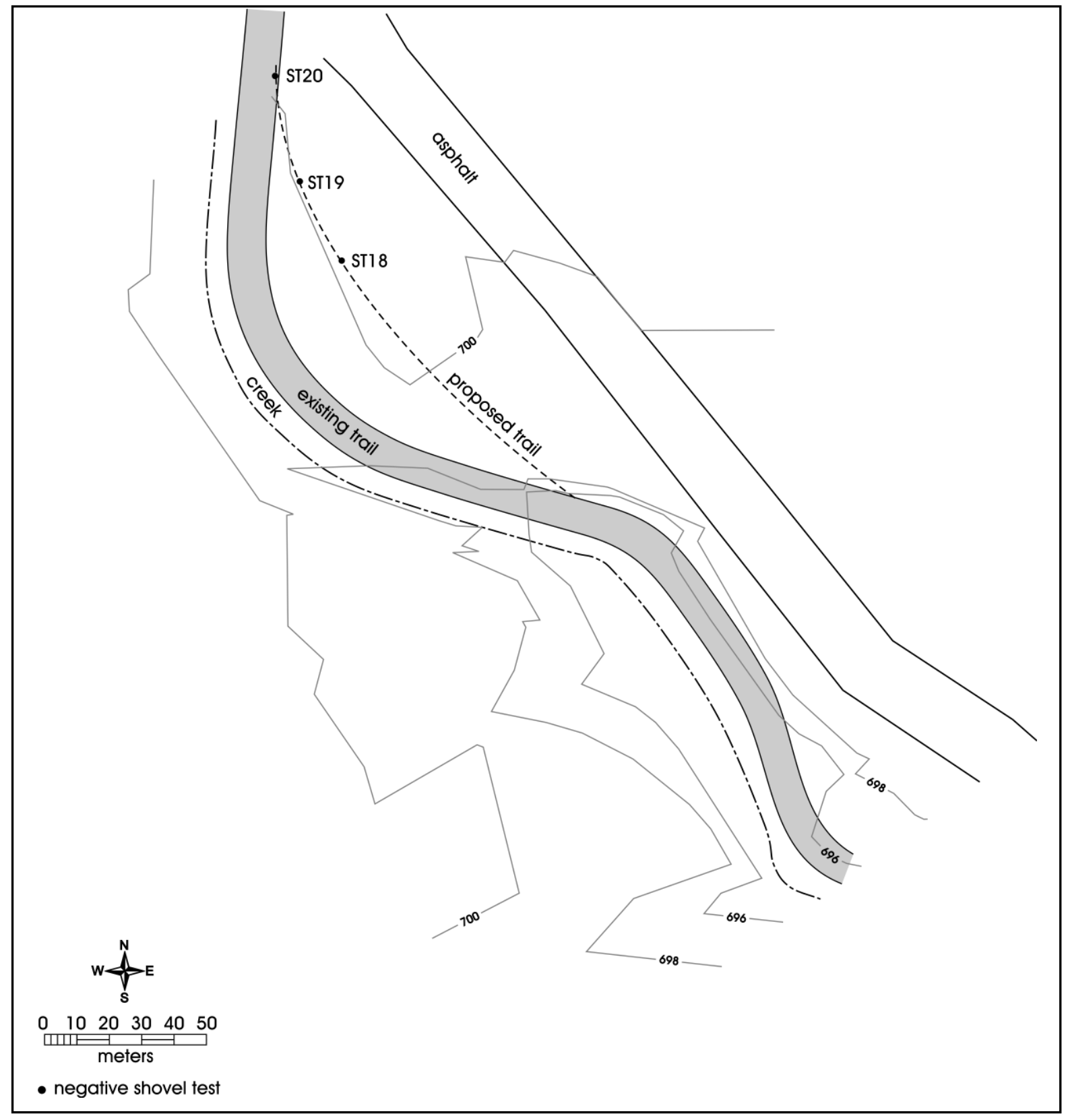

Figure 4-5. Map showing shovel tests in Area 4. 


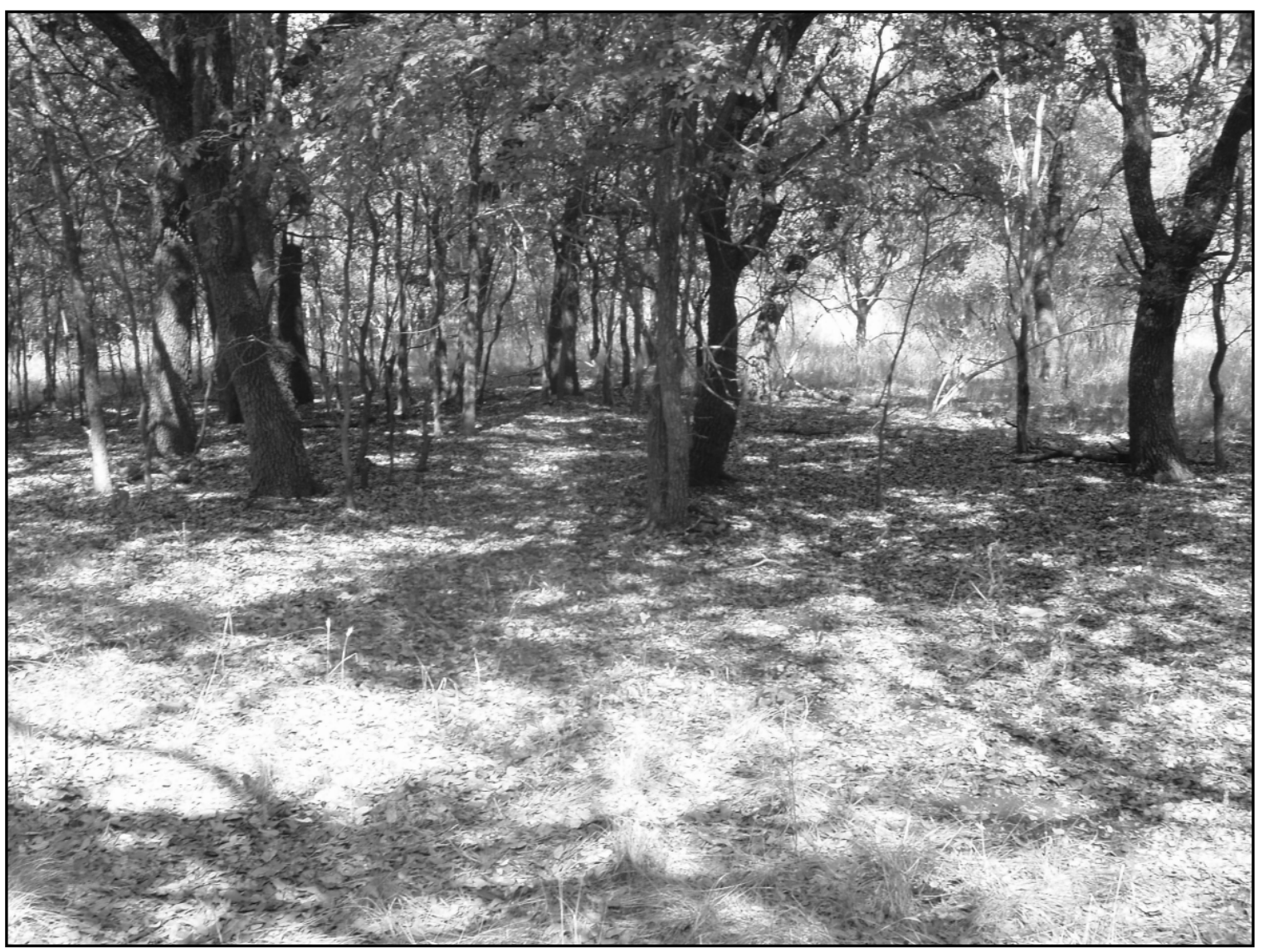

Figure 4-6. Location where new trail will be placed, Area 4.

Soils encountered in Shovel Tests 18 and 19 ranged from medium to dark brown silty clay loam that reached a depth of $60 \mathrm{cmbs}$. Shovel Test 20 contained a light brown silty soil with 10 percent gravel in Levels 1 and 2. The shovel test was terminated at $26 \mathrm{cmbs}$ due to large cobbles (Table 4-1). No cultural material was encountered in Area 4.

Area 6 (Figure 4-7) is located in the eastern portion of the park and includes the Optimist Park and Pavilion \#2 Restroom (Figure 1-2). Proposed improvements in this area of the park consist of relocating the pavilion and playground to an area just to the north. Vegetation was sparse to moderate with an abundance of mesquite, prickly pear and grasses (Figure 1-8). Ground visibility in the area was fair (60 percent). A total of five shovel tests was excavated in
Area 6 (ST 37-41). Soils in this area consisted of a silty clay with a moderate amount of pebbles. There was only one positive shovel test (ST 39) excavated in the area (Figure 4-8). It contained a single piece of lithic debitage in Level 2 (Table 4-2). The cultural material from Shovel Test 39 was documented as an isolated find due to the absence of artifacts in the other four shovel tests (Table 4-2), excavated within meters of each other.

Area 8 (Figure 4-9) is adjacent to lower Bee Tree Drive. The proposed improvements in this area will consist of expanding an existing parking area into a gently sloping, tree-covered area to the southeast. The tree line where shovel tests were placed was moderately vegetated with prickly pear and mesquite (Figure 4-10). Three shovel tests were 


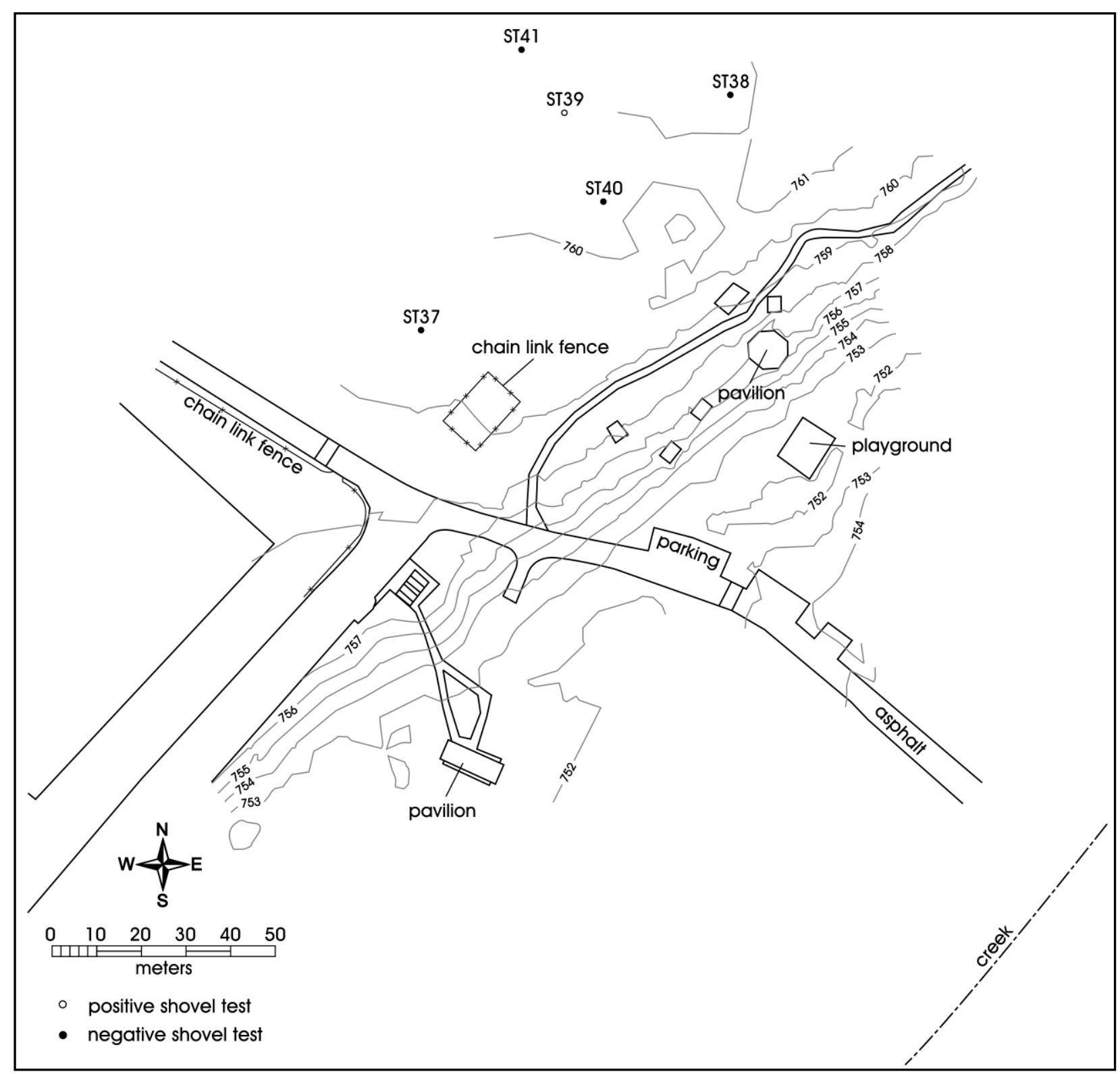

Figure 4-7. Map showing shovel tests in Area 6. 


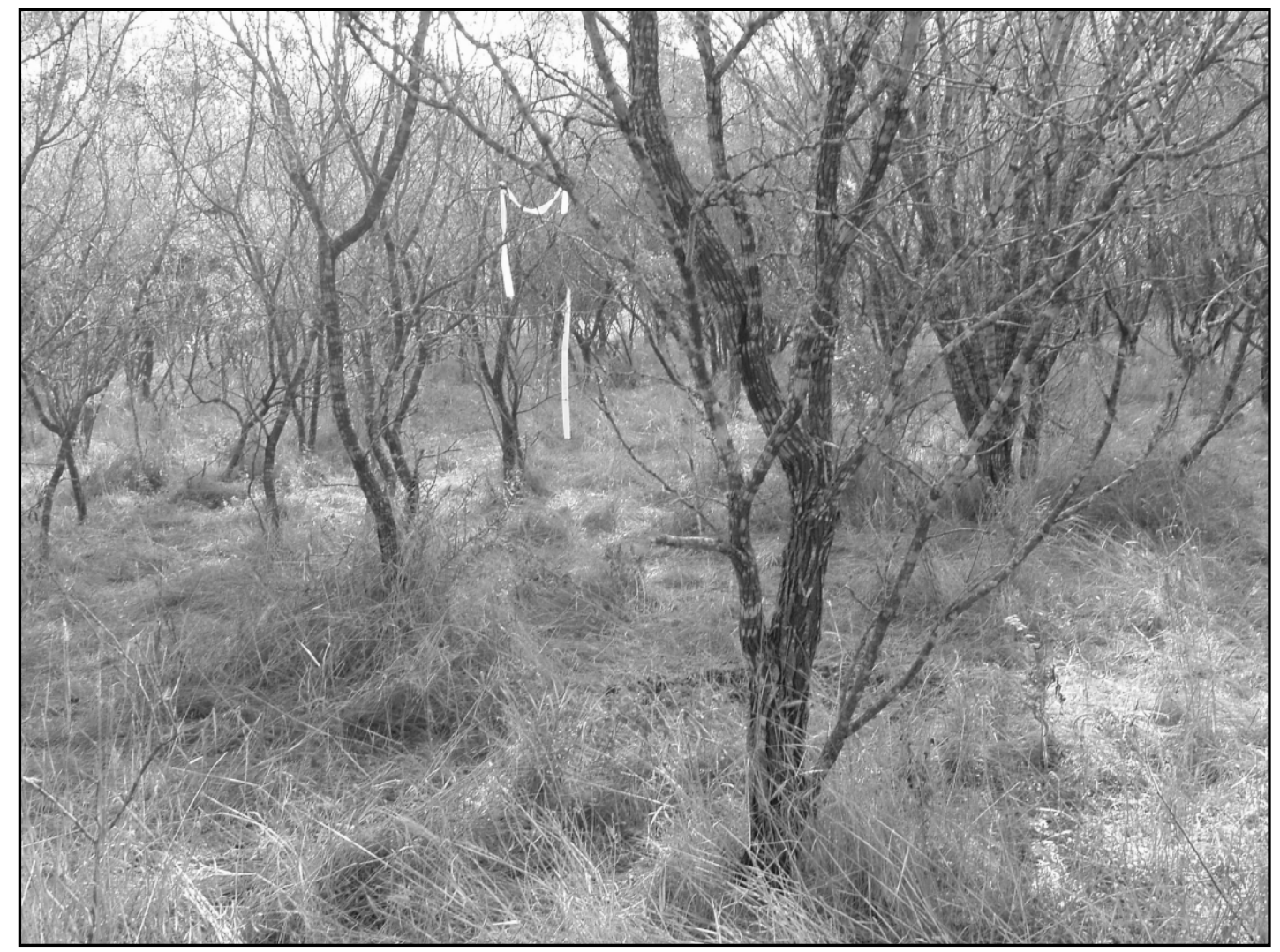

Figure 4-8. Flagging tape that marks positive Shovel Test 39 in Area 6.

excavated in this area (ST 34-36). All three shovel tests were located at the bottom of the sloped area. Shovel Tests 34 and 35 were terminated at $40 \mathrm{cmbs}$ due to a high concentration of gravels that made digging difficult (Table 4-1). Shovel Test 36 reached $50 \mathrm{cmbs}$. No cultural material was encountered in Area 8.

Area 9 is located in the southern portion of the park (Figure 4-11). Proposed improvements to this area consist of building sports practice fields. As noted in the scope of work section, approximately 50 percent of this area has been impacted by landscape modifications associated with the construction of an earthen berm that is located in the eastern portion of the area (Figure 4-12). The northern edge of 41BX959 is located along the southwestern edge of Area 9 (Figure 4-11) and was revisited and shovel tested by CAR in 2005 (Figueroa and Thompson 2005). The site's cultural deposits were found to be very shallow and heavily disturbed by landscape modifications. A total of five shovel tests were excavated in Area 9 during this survey (ST 5-9). Soils encountered in the shovel tests consisted of dark brown clay loam. No cultural material was encountered. Gravels were present in shovel tests and appeared to increase in the lower levels.

Area 10 (Figure 4-13) is to the southeast of Area 9. Proposed improvements to this area will consist of a Dog Park. The southern and central portion of the area appeared to be disturbed as indicated by the presence of construction debris piles and asphalt (Figure 4-14). Seven shovel tests were excavated in this area (ST 10-16). Shovel Tests 10, 11 and 14 only reached a depth of $10 \mathrm{cmbs}$ due the presence of asphalt and gravel fill that made excavating difficult (Table 4-1). One piece of historic green glass (soda) was recovered from Level 1 of Shovel Test 14. Given its recent origin no additional shovel tests were excavated in its vicinity. Gravel fill was evident in the remaining shovel tests and in Shovel Test 16 gravels reached a depth of $60 \mathrm{cmbs}$. 


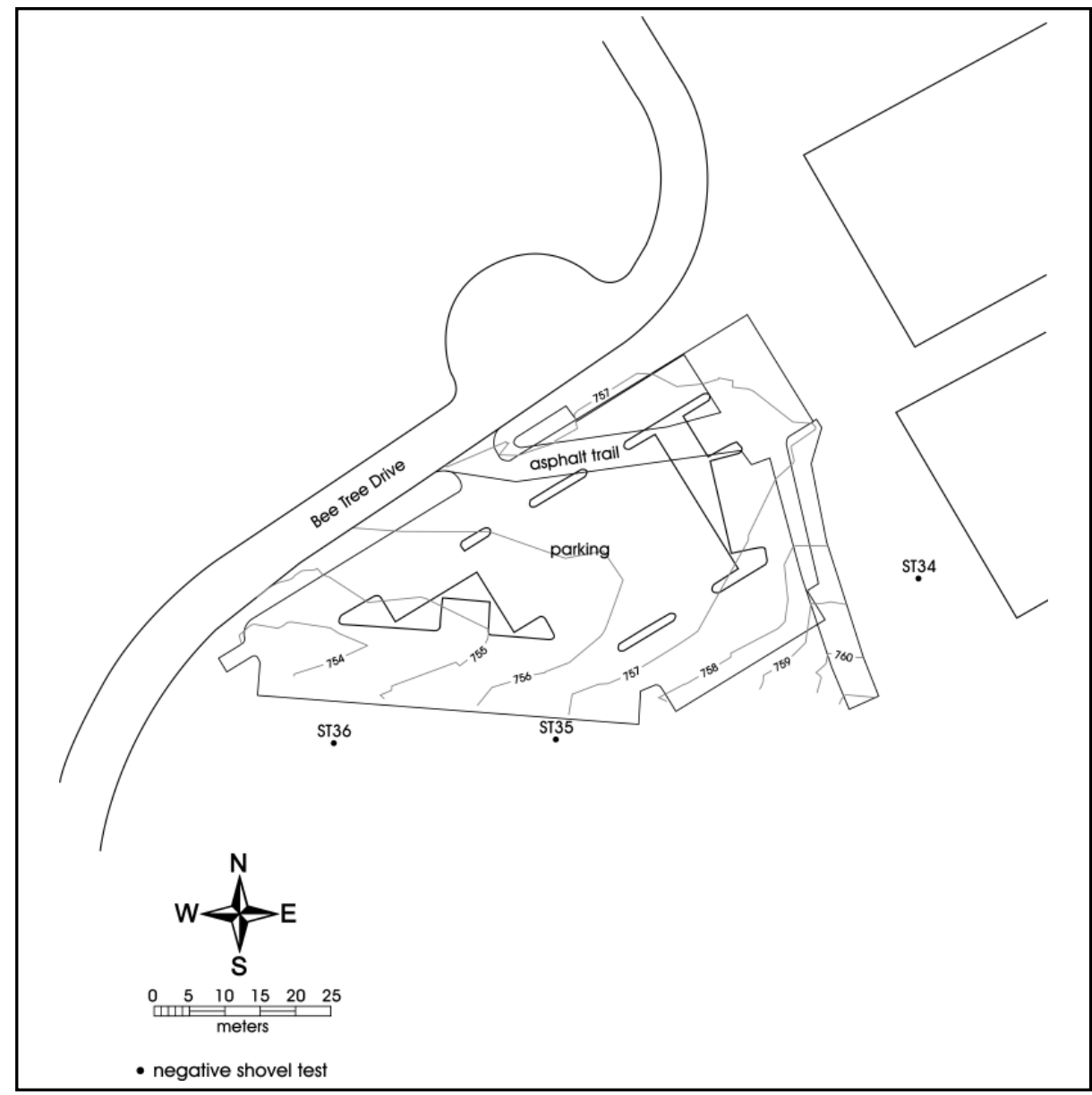

Figure 4-9. Map showing shovel tests in Area 8.

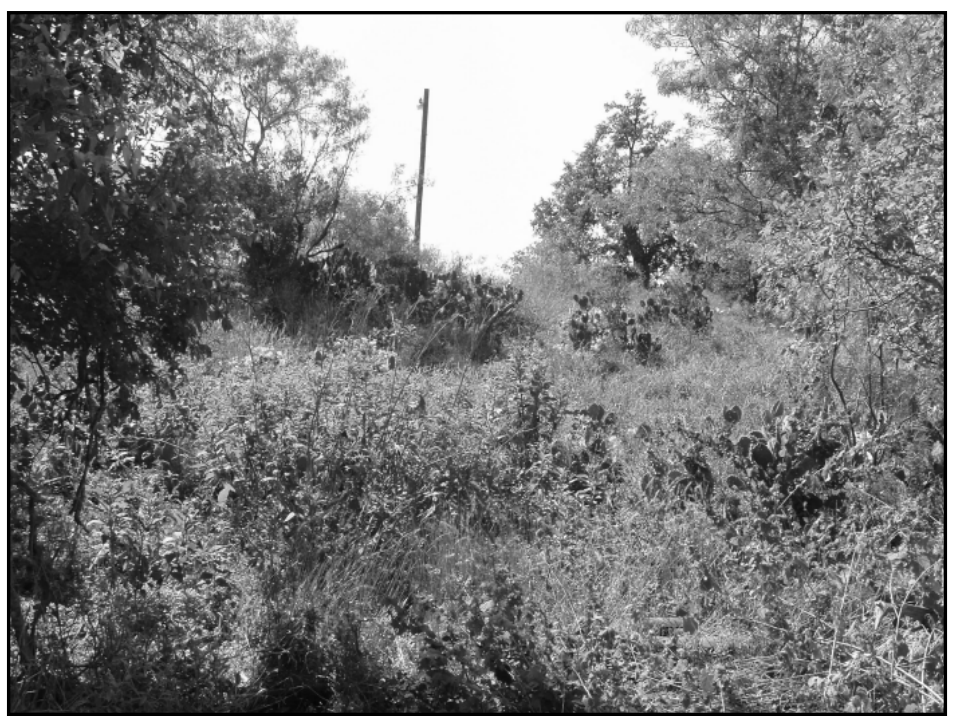

Figure 4-10. Vegetation in Area 8, the proposed parking lot adjacent to lower Bee Tree Drive. 


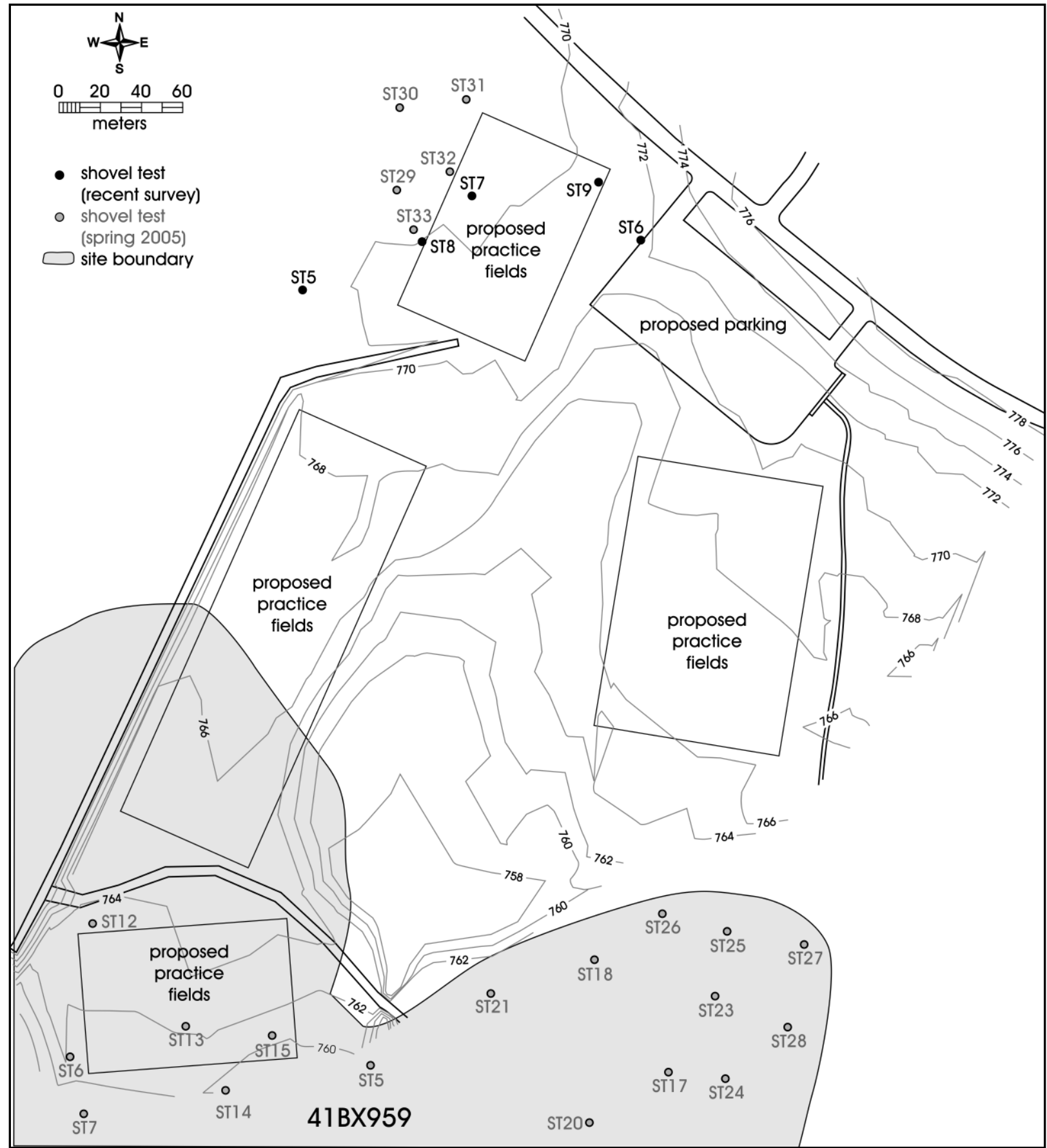

Figure 4-11. Map showing shovel tests in Area 9. 


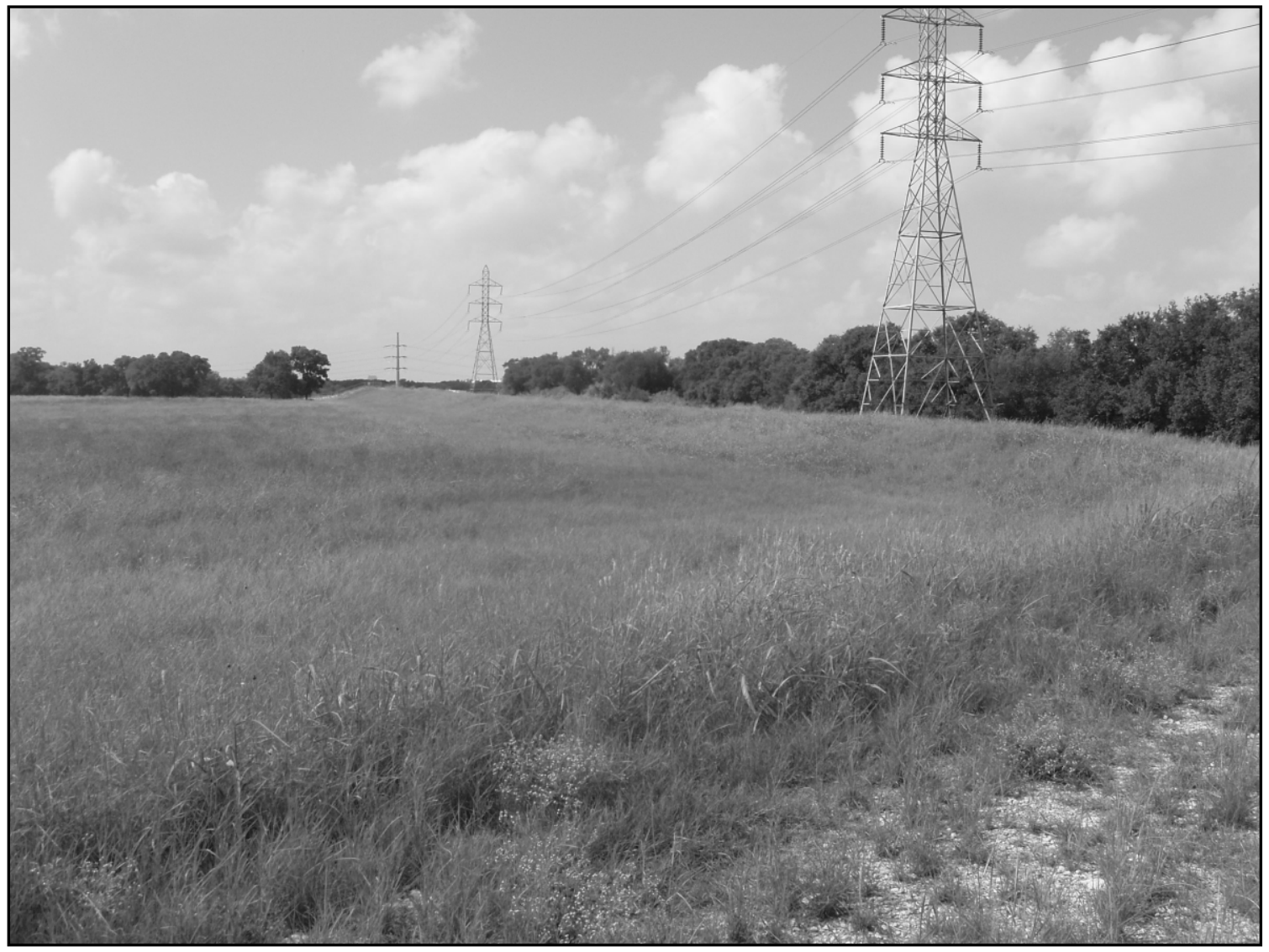

Figure 4-12. Earthen berm and power lines located in the eastern portion of Area 9. 


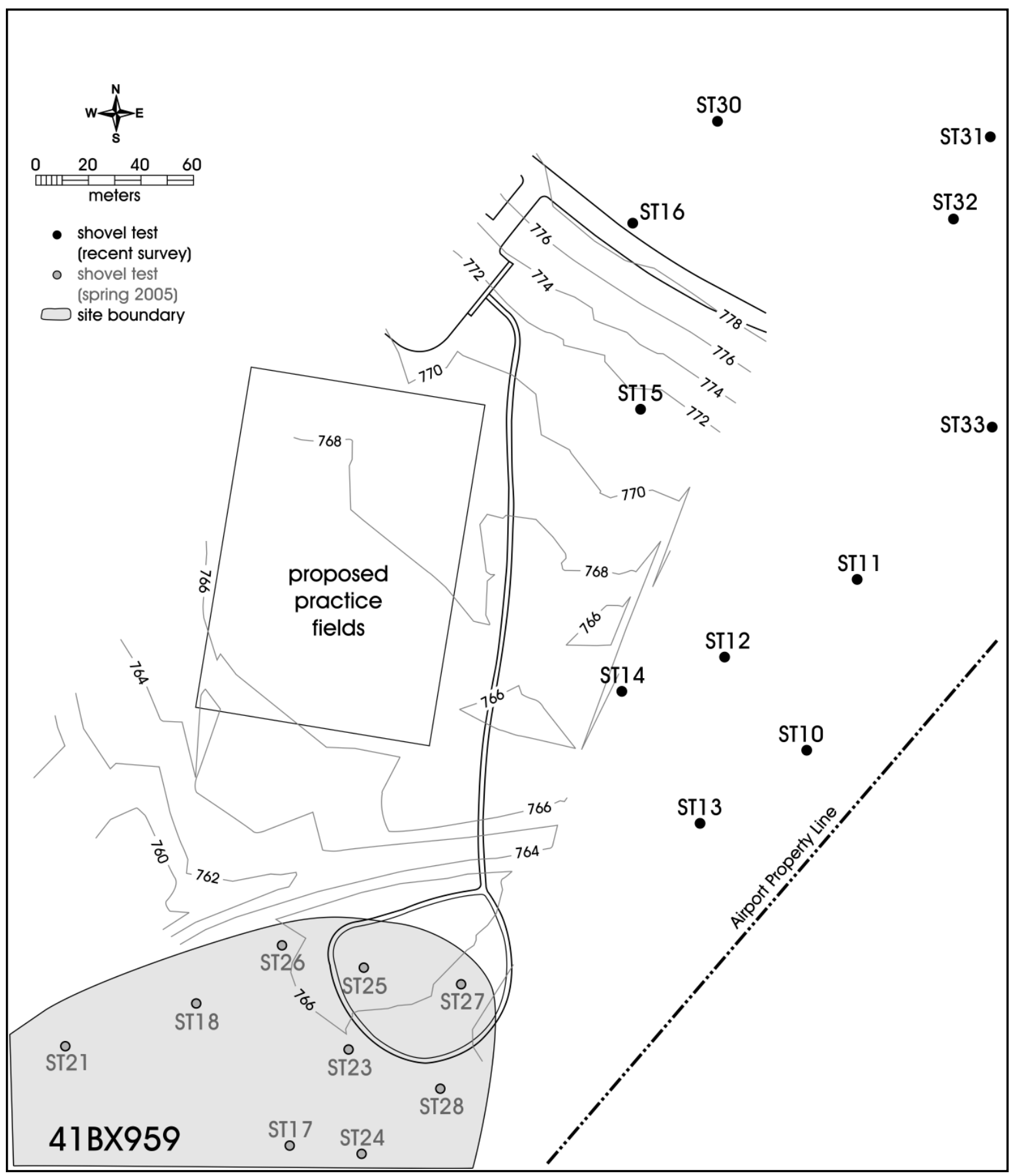

Figure 4-13. Map showing shovel tests in Area 10. 
Area 11 is to the northeast of Area 10 along the northern and western margins of the Little League Fields (Figures 4-15 and 4-16). The pedestrian survey in this area included the excavation of six shovel tests along a proposed water line that will be installed along the northern edge of this area. An additional seven shovel tests were excavated in the remaining L-shaped area along transects that were spaced $30 \mathrm{~m}$ apart. Vegetation in the area was moderate to dense and ground visibility was fair. There was a small drainage that crosscut the central portion of the proposed water line route. Several dirt trails also intersected the area. Soils encountered in shovel tests, along the proposed water line, consisted of a dark brown clay loam that was void of cultural material. The northeastern portion of the area was heavily disturbed by construction debris and bulldozing activities, represented by push piles of soil and debris (Figure 4-17). The shovel tests in the southwestern portion of the area revealed a dark brown clay matrix with a frequent presence of pebbles and cobbles from 30-60 cmbs. Vegetation appeared to be denser in this portion of Area 11. Large cobbles were present on the surface and along an old wood-post fence line (Figure 4-18). A 1953 version of Longhorn, Texas 7.5' USGS topographic quadrangle depicts structures to the northwest of Area 11 (Figure 4-19). The fence line may be a remnant of fields used by these homesteads. No cultural material was encountered in this area.

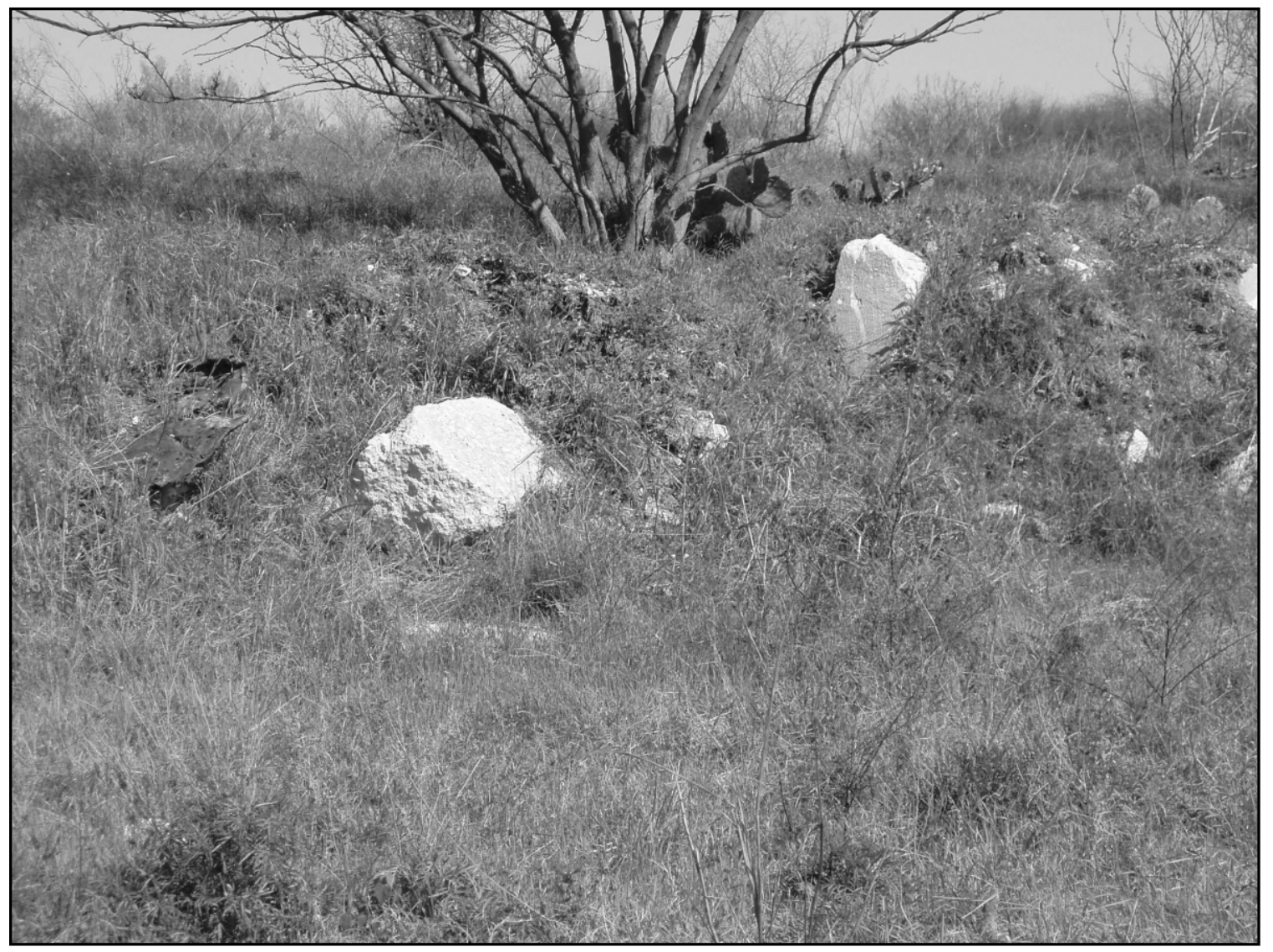

Figure 4-14. Construction debris pile in Area 10. 


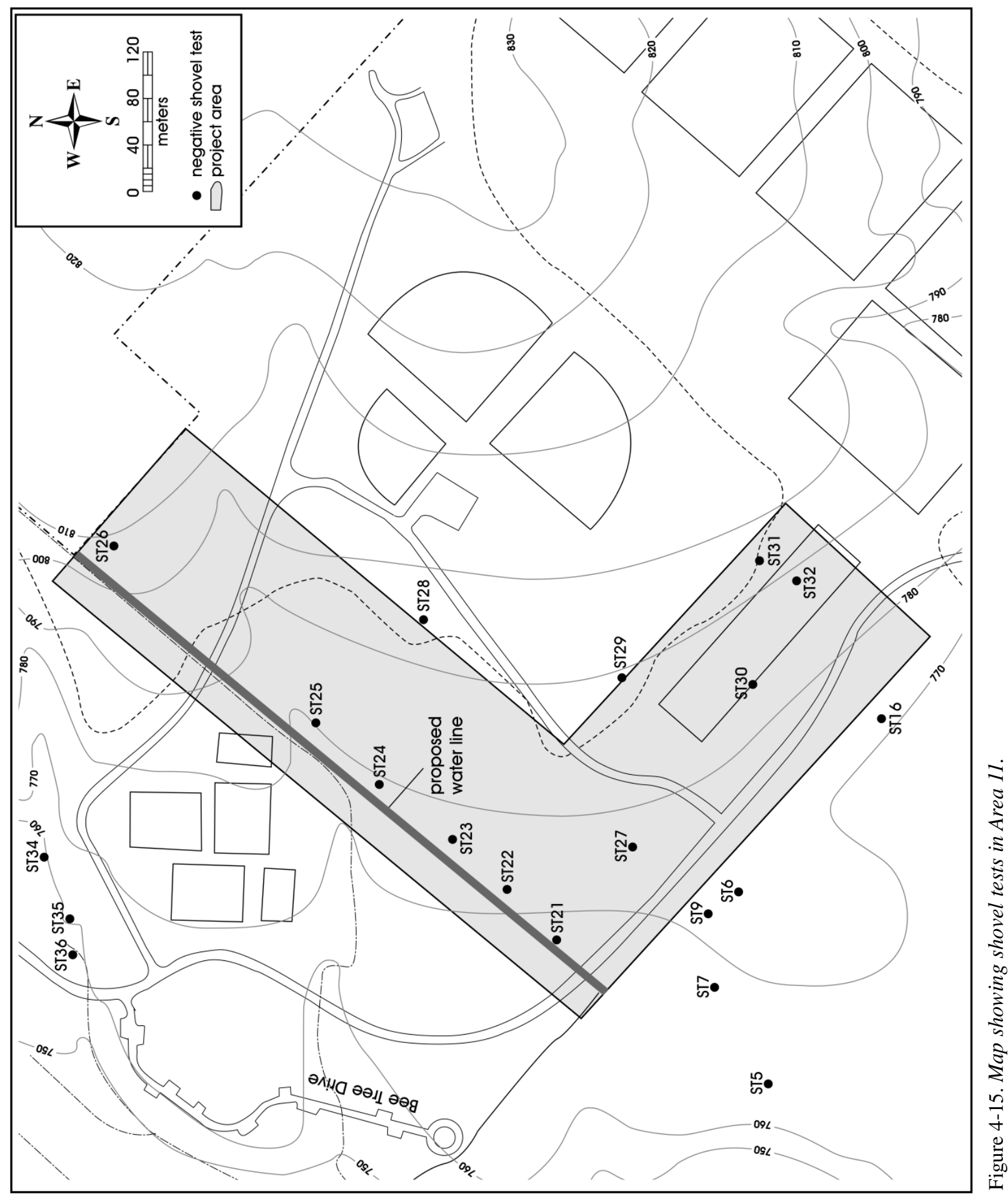




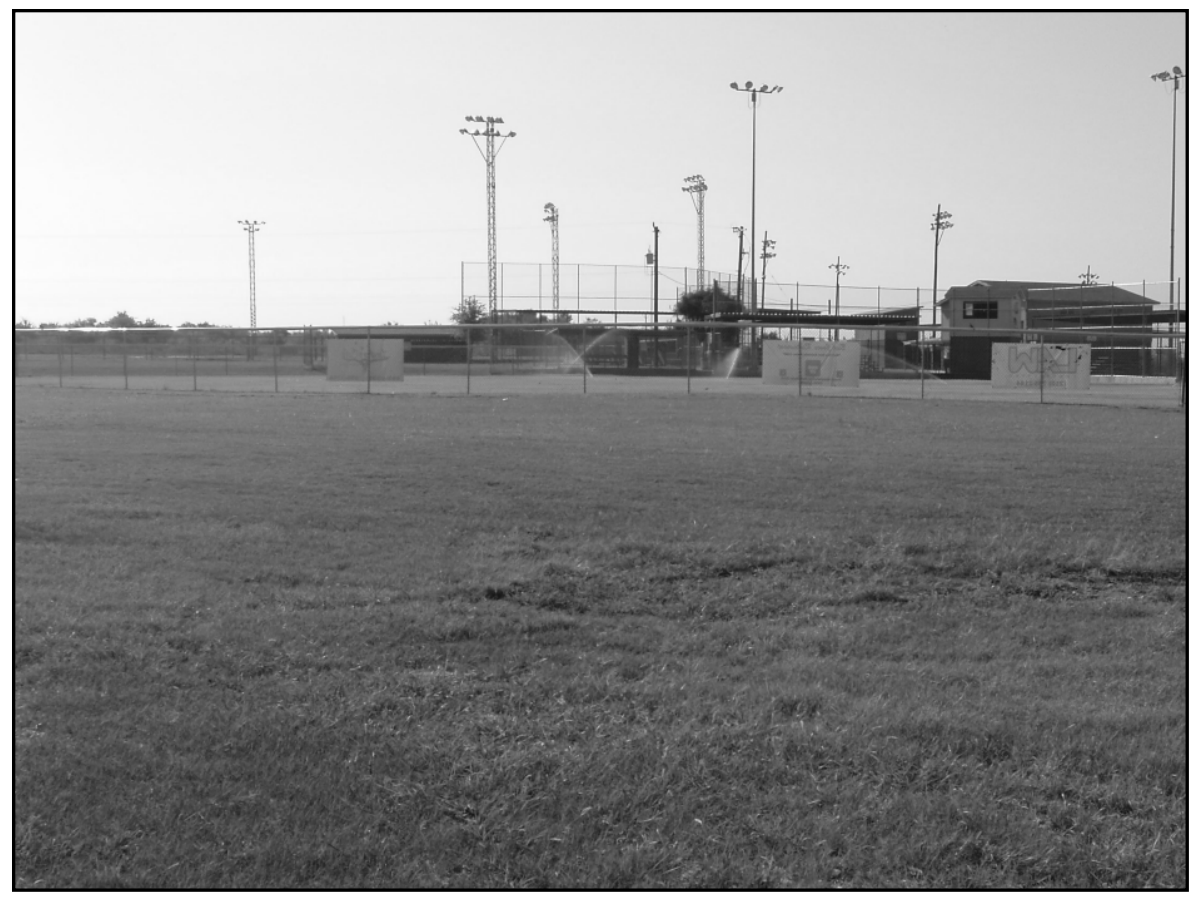

Figure 4-16. Little League fields in the southeast portion of Area 11.

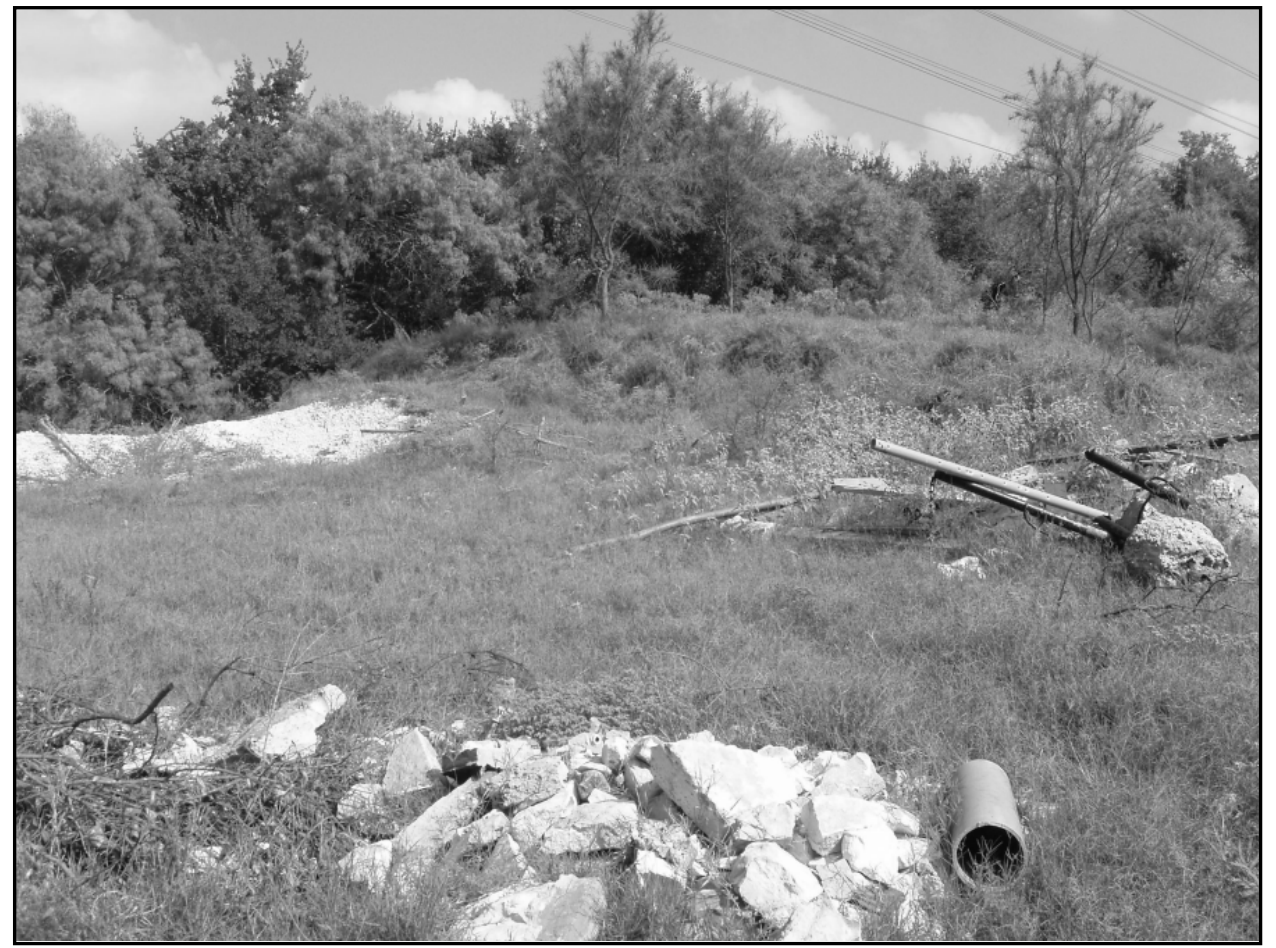

Figure 4-17. Construction debris and disturbance along the proposed water line in the northwest portion of Area 11. 


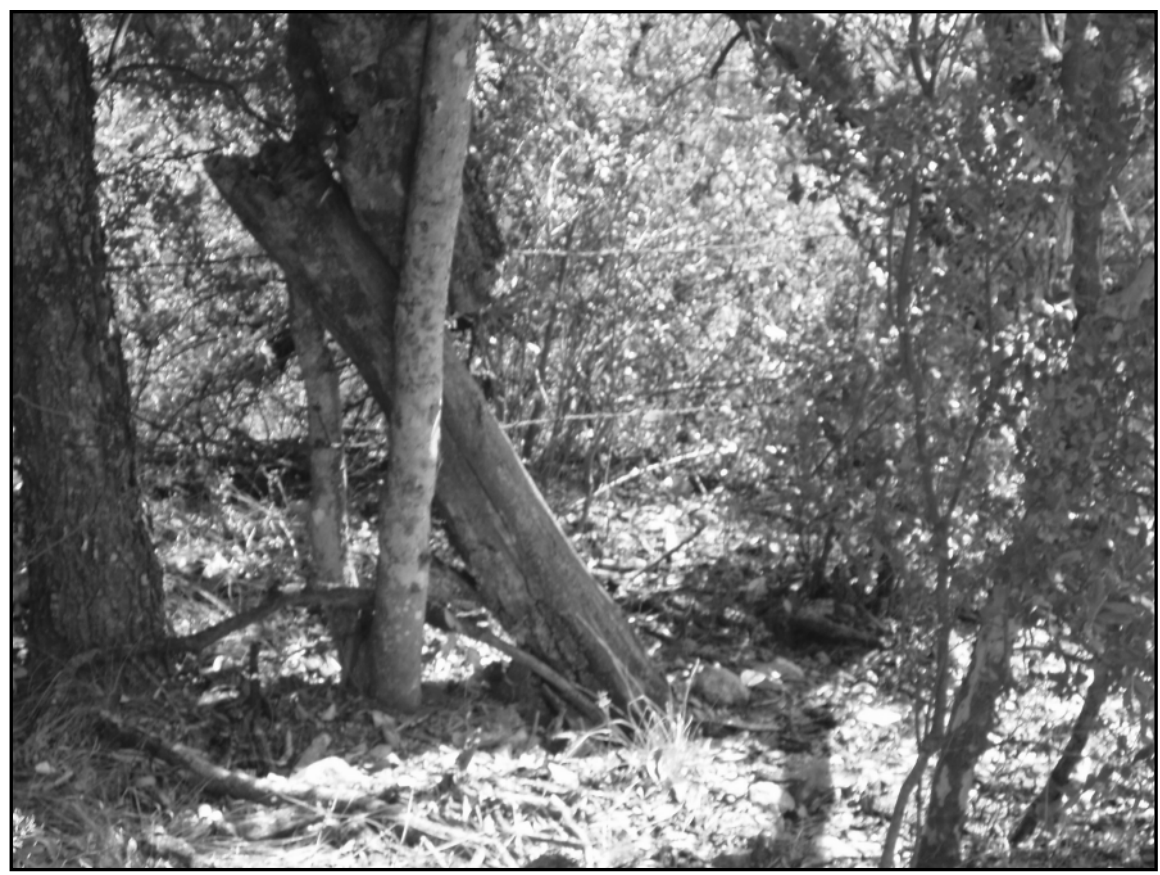

Figure 4-18. Old fence line encountered in the southern portion of Area 11.

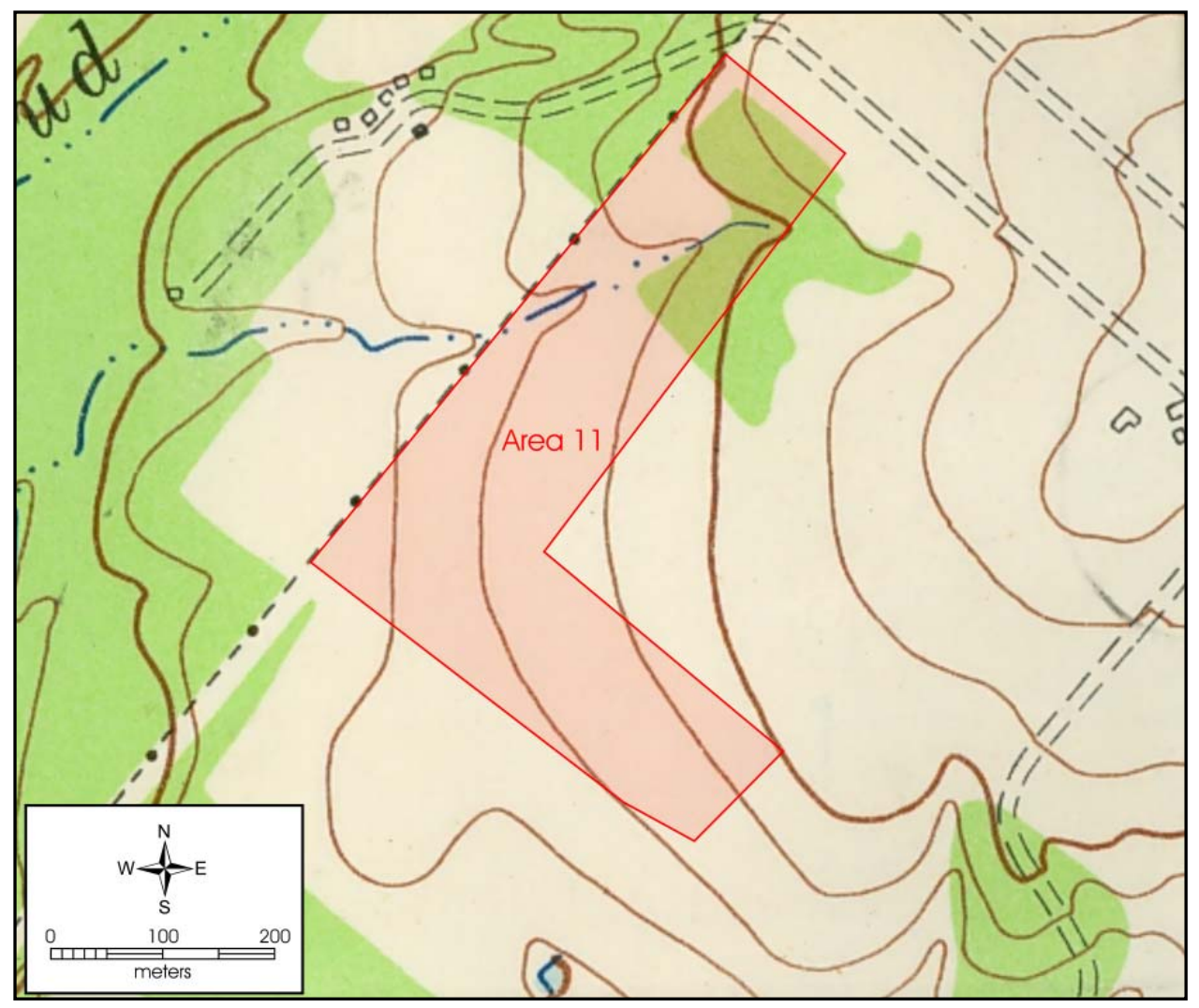

Figure 4-19. Area 11 depicted on the 1953 Longhorn, Texas 7.5' USGS topographic quadrangle map. 


\section{Transcript and Results of the Oral History Interview}

On October 19, 2005, an interview with longtime San Antonio resident Marvin Klar was conducted by Steve Tomka and Joey Thompson. The purpose of this interview was to collect an oral history of the land that is now McAllister Park, the surrounding area and the Klar family. Mr. Klar was a prime choice for this query, as his family owned the land for several generations before its conversion into a San Antonio city park. The interview lasted for approximately one hour and consisted of a series of questions deemed pertinent to the cultural significance of the land and its inhabitants. From demography and economic patterns to music and foodways, this conversation with Mr. Klar yielded valuable information unattainable except through the memories of the people who lived them.

Mr. Klar was kind enough to supplement his memories with copies of his family's land records. Without his cooperation, access to the information presented here would not be possible.

The transcript from that interview follows below. In an attempt to sustain the local speech patterns devices such em dashes (-) are used to represent pauses, interruptions, and other incomplete thoughts and laughs. Inaudible words are set apart by parentheses. Also, words such " $y$ 'all" and "gotta" are retained in the transcription to maintain the integrity of the dialect. A copy was made of the original tape and is housed along with the transcript at the Center for Archaeological Research:

Marvin Klar: That was, uh, that was around 65 that the, uh, that the city took it over.

Steve Tomka: Really, no kidding, wow. And that, that property went all the way down to the airport area right or that - ?

MK: Right.

ST: Wow.

MK: Actually, where the uh, the end of the runway is at this time right now.

ST: Uh huh, Starcrest - right there Starcrest.
MK: No, a little bit further up where uh, where the actual runway stops.

ST: Yeah, ok, gotcha. Where it's cleared right at the, at the end of the runway there's a little building?

MK: Where the actual run - yeah there's a little building I guess where they've got their, their uh, electrical something -

ST: Something I don't what it is, yeah.

MK: - whatever, there's a little house sitting there. That's where my dad was born and raised

ST: Really no kidding.

MK: That's where the Klar homestead had been.

ST: Used to be. Right there no kidding.

MK: Yeah, where it's actually at yeah.

\section{ST: Holy cow.}

MK: Fact is when you go down Wetmore Road, you'll see, where they've built that Wetmore Road there they actually left out a little.

ST: Uh huh, portion of it?

MK: Portion of the curbing that went into that area.

ST: No kidding so there's the entrance to the Transportation Museum right there off Wetmore?

MK: That's further up yeah.

ST: That's a little bit further up to - ?

MK: Yeah, that's further.

ST: Wow. How awesome? So, so when the airport took it over they basically flattened the, your old homestead?

MK: Yeah, oh yeah yeah everything was wiped out when they did that back in the, the early, early $60 \mathrm{~s}$. 
Joey Thompson: Early 60s?

MK: I guess around 61, 62 something like that.

ST: So your dad held on to some property for a while longer after that?

MK: Well actually -

JT: McAllister Park happened after?

MK: Yeah actually on the uh you'll see it on that first page. These are the tracts -

ST: 5,000 by 5,000 .

MK: - where we kept 3 acres I believe that where it's at.

ST: Wow.

MK: This might be a different part of it. Well we had, my sister had built a house in, on the uh homestead there.

ST: Oh really.

MK: And then when we got married we got married my wife and I got married in 62 we built, and then when the city took everything out my mom and dad built a house right there with us.

ST: Oh really.

MK: Yeah so there's 3 acres each, each house had an acre of land with it.

ST: No kidding. And this was up where the where the uh the remnants of the foundations are still up there by that by the road Bee Tree Road Bee Tree uh -

MK: Yeah.

ST: Up in that area where we were doing the excavations did you I don't recall you ever coming out to take a look at our digs out there?

MK: Yeah I was by there a couple of times.
ST: Were you? Ok.

MK: Yeah, y'all were doing something.

ST: So that homestead was right next to it is that right?

MK: That, there's an old concrete cistern.

ST: Yeah that's right.

MK: Right, yeah, that - my dad built that.

ST: Ok.

MK: I was, I was probably about 6 years old.

ST: No kidding.

MK: or 7 years old when he built it.

ST: Did you get to help?

MK: I helped a little bit I wasn't -

ST: A little bit - not much at that young of an age?

MK: I couldn't - I wasn't old enough to do a whole lot at that time.

ST: By the way we talked that we were going to record you I hope you don't mind - which I think it's on?

JT: Yeah it's on.

ST: Because otherwise we can't write and I'd rather listen to you than have to write it down by hand.

MK: Yeah.

ST: So it really helps us quite a bit.

MK: Yeah you had told me you were gonna.

ST: I do appreciate it because otherwise I forget it if I don't write it down - it won't stick around.

MK: I don't know exactly how, - that's, that's what I want to find out when we have the reunion is when Paul Klar - 
when the actual, where I was telling you where the actual homestead where my dad was born.

ST: Yes, the original.

MK: Yeah. When he actually purchased that land and how that all came about I don't know if uh if he bought all that land up at that time and went from there and then each boy got a portion of it as they got married.

\section{ST: Portion of it sure.}

MK: And then each one, each one of the boys started a dairy.

\section{ST: Really?}

MK: Yeah they were all in dairy farms.

ST: Wow.

MK: And I know it was probably in 193- about 1932 when my dad started, when they got married and started a place there.

ST: Uh huh.

MK: Where that cistern was.

ST: Ok, the original house was built when in the1800s down there by that little building?

MK: Uh, the actual house that they lived in was actually a barn.

ST: Really?

MK: That they remodeled into a house and then added, kept adding on to it.

ST: That was over by the cistern?

MK: That was just up from where the cistern was.

ST: I'll be - wow. Are there any drawings or any photographs?

MK: I've got some old photographs.
ST: If you have something that shows the house we would love to put it in the publication. We can make a color copy of it or scan it and stick it in the publication in remembrance of the old Klar home.

MK: Yeah.

ST: That'd be fun.

MK: I know the up above - are you familiar with where the Ancira sports park is at?

ST: Dealership? Oh yes, yes. I know where that is yeah I drive I drive by it a lot going to work everyday.

MK: That was, that was my uncle's place one of the other uncles that was Robert Klar's place now the old dairy barn is still sitting down there.

ST: Oh really.

MK: The house is gone but the old dairy barn is still there.

ST: They kept it there?

MK: Yeah, if you go up in other words uh right next to Ancira.

\section{ST: Uh huh.}

MK: The uh, my dad and the city had made a, a uh gentleman's agreement way back when the city bought that land if they would take care of that road that they could use it as a maintenance road.

ST: For the park?

MK: For the park.

ST: Ah, oh ok.

MK: And that's where the Cavalier's bleachers and all that stuff stays they go in and out that back road rather than trying and go through all the trees and all that stuff to take bleachers out all the time.

ST: Sure, sure. Oh ok that makes sense. 
MK: So that road goes down to those 3 acres where we live at. Right there's that little cut off that goes right down to where the dairy farm is, that goes down to the soccer fields and all that through the trees through the park and all that where they, where they pick up all the, you know where all the when it's time to pick up all the bleachers to take - for all the parades and all that stuff that's the way they go through there.

ST: That's amazing. So, you're family originally immigrated into the states back in the 1800s I presume?

MK: Yea, I don't know the exact date when I don't - Grandpa Klar who used to have the homestead there right where the runway ends, he was on the boat with his parents - that was Joe and Josephine and they settled in Bulverde.

\section{ST: Oh ok.}

JT: So they came straight to Texas?

MK: They came straight over in here and uh there was one, I think there was 4 children, one of them died and was buried at sea on the way over.

ST: Mmm, wow. That must have been a hard journey coming across. Not like today where you can do it in a week or 2, I'm sure it took months.

MK: (laughs) Yeah, quite a bit of difference, yeah.

JT: What was your Grandpa's name, the one was born uh Joe and Josephine's you said right?

MK: The ones that came over from Germany was Joe and Josephine.

JT: Oh ok.

ST: Yeah we have a list of questions we want to make sure we get some information from you instead of starting to talk and forgetting about some of the stuff that we need to ask. Joey here -

JT: Yeah well we're covering good kind of stuff here. I guess I could uh get you to state your full name and when and where you were born for the, uh, for a record of it.
ST: For the record.

MK: Well, my name is Marvin Klar. And I was born there on the on the uh that place where we were talking about where that cistern is. I was born there in 43, 1943-

JT: Right. Ok wow. And you said that the Klar family came from Germany. I'm presuming, I guess early or mid 1800s something like that?

MK: Yeah I don't know the exact dates.

JT: Yeah, yeah, yeah.

ST: Do you have a geneaology - anybody in the family. It sounds like you've got a pretty good extended family putting together a family tree or -

MK: Yeah.

JT: That's great.

MK:We're gonna work on a lot of that on this reunion.

ST: They're spread around the state or there's even some folks out of state now?

MK: There's some out of state, but most of them are in the state.

ST: Be good to see them.

MK: It's gonna fairly interesting trying to get everything together.

ST: Yeah I bet and I'm sure some of them you haven't seen in quite a while. Grandkids -

MK: Yeah, yeah, yeah...

ST: Some grandkids you haven't seen in a while.

JT: Do most of them live in the San Antonio area or are they just scattered all over.

MK: Mainly scattered all over. 
JT: Yeah. Do know how much of the land that is McAllister Park - do you know how much of that y'all owned? Was it all of that?

MK: Probably, no it wasn't all of it.

JT: Ok.

MK: I would say there was probably about 1500 acres.

JT: Ok.

MK: That was in amongst the, the uh Klar family, the four Klar brothers; and that was all in dairy.

JT: Uh huh.

MK: All four of them had dairy farms.

JT: Did they uh, did they rent the land out to anybody or did they all - it was all kept in the family and used for dairy?

MK: Yeah, it was all kept in the family all used -

JT: All dairy?

MK: Yeah.

ST: The dairy - did you clear all that land out - was that at one point just pasture or - did you clear much of it how was that - ?

MK: Most of it was already in fields and stuff like that cleared out.

ST: We haven't yet had a chance to look at some the historic aerial photographs. I understand I can get a hold of some go back, going back to the 1930s. Take a peek and see what the land looked like.

MK: That would be, that would be interesting.

ST: Yeah, yeah that should be fun. You can get it apparently at Topo - what used to be Topo and Aerial, they carry that kind of stuff. We'll try to gather some from the 30s or 50s kind of see how things change over that time.
MK: Yeah, yeah.

JT: Do you know if that area was always a part of San Antonio or was that called another community at one time? Did that have a different name or was that always part of - ?

MK: That area there, and it's still more or less, they call that Wetmore.

JT: Wetmore, ok.

MK: Yeah and it's uh there's a little store used to be uh used to be uh uh post office and a grocery store and a family -

JT: Right.

ST: A family business?

MK: A family - a beer joint.

ST: Where is that at? On Wetmore?

MK: Yeah, it was right on the other side of Thousand Oaks.

ST: Yeah. Ok, I know -

MK: It's the uh the original store is still there.

ST: Yeah and there's a restaurant in it now.

MK: There's a restaurant.

ST: I drive it - my son goes to daycare right just south of that intersection at uh what is that doggone childcare - La Petite. There's a little childcare center right down the hill where the railroad tracks cross there. And so I drive down that way quite often.

MK: Uh huh yeah. Fact is they, even somebody, a few years ago I don't know I'd say maybe about 8 years ago somebody spent a lot of money - they picked that sucker up - the whole store and moved it back probably.

ST: Away from the curb?

MK: 15,15 feet or so back. 
ST: Holy cow yeah that must have been a pretty penny.

MK: That's, it's bound to cost pretty good amount. But that is the original old store.

ST: No kidding. I'll have to go in I'll have to stop now go in take a look at it.

MK: It's still the old - It still has the old wooden floor.

ST: How neat, I'll be dogged.

MK: They used to have their own 9 pin bowling alley in there too.

\section{ST: No kidding.}

MK: Which was, it was situated between that store uh and the, there's a house - real pretty white house -

\section{ST: Yeah right next to it.}

MK: Right next to it. Well that house, in between those two there used to be uh a uh -

\section{ST: Bowling alley?}

MK: A bowling alley in between those, which was 9 pin bowling.

ST: You spend a lot of time there as a kid?

MK: I used to set up pins. That's how I made my spending money.

JT: How many lanes - how many lanes?

MK: Just 2 lanes.

JT: 2 lanes - There's a place up in uh Bracken, a bar -

MK: Yeah, it was about the same size.

\section{JT: Kind of the same?}

MK: Yeah, kind of the same kind of town.
JT: There's a bar up there and the bar is made out of the old bowling lane wood. Let's see oh uh - were there churches or schools and stuff in that community as well - in Wetmore? Did you go to school there or - ?

MK: No I went right here in Alamo Heights. St. Peter's Catholic School is where I went.

JT: Oh ok.

MK: My brother went to Salado - they called it SaladoValley.

ST: That's no longer there I bet.

MK: Well that no longer exists.

ST: That was another little community?

MK: It was Salado Valley - I don't how many grades it went through.

ST: Had a little school house and everything?

MK: Uh huh, I don't where exactly it was located on - but that's where he went to school at.

ST: Ok, wow.

JT: So did y'all attend the Catholic Church there or - ?

MK: Uh huh.

ST: So when you grew up did any of the families speak German?

MK: Oh yeah. That's all we spoke was German at home but uh yeah.

JT: Wow.

ST: Yeah, I myself came out of Eastern Europe from Romania so my parents speak Hungarian and Romanian we're from that part of the world but my kids don't know any Hungarian or Romanian. When we go visit my parents, their grandparents, my kids' grandparents they hear it and they pick up a few things here and there but it doesn't stick with them very long. 
MK: Yeah well I always thought when my second oldest brother got married, he'd come home he'd he used to make the comment you know "I gotta think before I can talk."

JT: Yeah, yeah.

MK: Agh, you're full of prunes you know - once you know the language -

ST: It doesn't go away.

MK: Right but the more and more now since my mother died especially I don't have anybody to talk with to.

ST: Sure.

MK: And man -

ST: It gets rusty. It gets rusty doesn't it?

MK: It's hard.

ST: It does.

MK: Now, now when I see one of uncles or something it's really hard to know exactly what he's talking about.

ST: Now you really have to think about it

MK: Right now you have to think before you talk. It makes a lot of difference.

ST: It sure does, that's interesting. Yeah I get on the phone with my parents and I'm the same way. You know, I have to think about it. You know, it's not automatic.

MK: No, it doesn't flow as easy.

ST: English, it's like that with English now didn't used to be Now it's Hungarian and Romanian - it's a struggle sometime. I still can read it and understand it and all but it just doesn't come as easy.

MK: Yep.

ST: When did your grand-, uh your mom pass away?
MK: It's been about 4 years now.

ST: Here in San Antonio?

MK: Nodded yes

ST: Sorry to hear that. And your dad did he live on for a while or - ?

MK: He had passed on about 8 years before that

ST: Oh.

JT: What about your brothers and sisters? How many did you have?

MK: I have one sister left, but uh I had uh - there was 4 of us -2 brothers and one sister.

JT: Y'all all stayed around San Antonio or - ?

MK: Yeah, everybody lived here in San Antonio.

ST: Was the dairy business a successful business?

MK: Yeah, it was - it wasn't too bad. I guess you could say thank God for unanswered prayers. (laughs) I was trying like hell to get back into the dairy business there for a while. And I found a place that had the whole setup and everything ready to go, but I couldn't get the uh -

\section{ST: Finance?}

MK: - the funding.

ST: Yeah.

MK: And it just kind of fell through.

ST: That's when you got his job here - when you took the job here?

MK: No, I was in construction, regular, but uh I been here 17 years with the city so -

ST: Yeah but as the country song says, sometimes those things you know just work out for the best. 
MK: (Laughs) Yeah it's, the dairy business is unforgiving. It's seven days a week.

\section{ST: Yeah boy.}

JT: It's a high tech operation now too.

MK: Today yeah two times a day and seven days a week.

ST: It's hard to compete with the big companies you know unless you're willing to go that way -it's just too expensive.

MK: And now there very few mom and pop operations around San Antonio.

\section{JT: It's vicious.}

ST: Yeah it's a shame. It's a way of life - unless you're just not going to compete, which it's a shame. That's how our whole country used to be, and especially in Texas. It was it, that was it. Beef, cattle and dairy you know all that is gone in most places. West Texas you still see some folks struggling. You know and there's still counties where you have it but it's on the way out.

MK: Yeah, ah yeah. Not much left of it.

JT: My uncle drives a uh a milk tanker truck and goes around all the dairies and picks it up for Meadow Gold milk company in Alabama I used to have to, I'd get up and go with him sometimes. The dairy business is too early in the morning for me. You have to get up at 3 in the morning start doing that stuff.

ST: Yeah, yeah.

MK: Oh yeah, yep I used to get up before I'd go to school and help do all the milking.

JT: Right.

ST: By hand?

MK: No we had, we had the uh electricity at that time but uh every once in a while you had to do it -

ST: Something go wrong? Yeah.
MK: Electricity yeah - electricity would go out or something, you'd have to go by hand but uh we were lucky enough to where we had the electricity so it wasn't that bad but uh bad enough where you had to get up before you'd go to school.

ST: Right after you get back have to do it all over again.

MK: Get back home, do it all over again.

ST: How many cows did y'all have?

MK: Usually, usually between 60 to 75 that were, that we were milking.

ST: Wow.

MK: That were actually milking.

ST: Y'all churn butter on your property too or sold it - ?

MK: No they sold it to a dairy. Very, in other words if they wanted some butter every once in a while they would but no -

ST: They'd churn some for consumption but not for sale.

MK: No.

JT: Did y'all keep any other family, uh any other animals besides cattle on the property?

MK: No we had chickens.

\section{JT: Chickens?}

MK: Just enough for uh - like hogs and stuff, raise enough for butcher.

JT: Right, just to eat yeah?

MK: Nothing for sale or anything.

JT: Right.

ST: Were you able to go out hunting at all in those days when it wasn't so overpopulated? 
MK: Yeah oh yeah.

ST: Game, deer?

JT: Lots of deer?

MK: I spent a lot of time on uh -

ST: Brought in some extra meat I'm sure, not that much but still, a good, good change of pace.

MK: Yeah. Oh yeah, I did quite a bit of trapping, yeah.

ST: Trapping?

MK: Sold the furs.

ST: Oh really?

MK: Yeah.

ST: Up to how long - 40s, 50s?

MK: Uh, I still ran some traps probably up to the - right before I got married.

ST: Really, when was that?

JT: What year?

MK: 60s, late 50s.

ST: On the property on that same property?

MK: Yeah, oh yeah.

ST: What were you catching in the traps?

MK: Caught coons, possums -

JT: Were the nutria up here yet?

MK: No, not that much.

JT: Right.
MK: Mainly the coons and possums and ringtails.

JT: Did your uh, your mom make most of the food, was it still like German influenced?

MK: Oh yeah, oh yeah.

JT: Yeah.

ST: Good home cooking. Did y'all have a big ole cold house or basement or something? That looks pretty rocky up there.

MK: No there wasn't no basement or nothing.

ST: Yeah there's no way of digging into that ground. Straight limestone after a few inches of clay.

MK: Yeah. Usually for uh, for like dried sausage and stuff we'd, we'd uh wrap'em in lard. They'd keep the sausages in the lard.

ST: Yeah that's, I grew up like that in Romania. We used to have hogs and we slaughtered a couple a year - January, December or January - we'd render the lard and store meat...

MK: Yeah.

ST: Cuts of, of chops basically as well as canned. And we'd have uh blood sausage, make blood sausage, liver and sausage, big slabs of bacon that we would uh smoke, we'd butcher and have it a good part of the year.

MK: Yeah, yeah.

ST: Y'all have a smokehouse out there?

MK: Yeah oh yeah.

ST: Separate from the rest of the property?

MK: No, it was, it was there not too far from - pretty close to where that uh, that cistern was.

ST: Cistern?

MK: It was all right around in that same - 
ST: Pretty compact little area.

MK: Yeah same area.

JT: What kind of food besides the sausage did she make that was that you would say was German?

MK: Pretty much what he was going through.

JT: Yeah. Pastries, stuff like that?

MK: Yeah

ST: Y'all have a garden out there?

MK: Yeah, oh yeah. She'd, my mother raised all kinds of vegetables - that would grow around here.

ST: Right, yeah in that clay soil right - that must have been a battle.

MK: Oh yeah.

ST: Just digging through it was a pain I tell you - try to raise anything in it -

MK: Yeah it still is. It still is...

ST: Yeah.

MK: We've got - we raise our own vegetables. Still got a garden going.

ST: Do you?

MK: There by the house there.

JT: What do y'all raise?

MK: Little bit of everything. You know, you know like right now we got cabbage and broccoli.

ST: Fall, fall stuff?

MK: Yeah fall stuff but uh the okra's still coming in somewhat.
ST: Yeah.

MK: But uh we use an organic fertilizer. We used to have a couple of milk cows there at the house -

ST: Natural fertilizer yeah.

MK: - when we had 6 kids there. That way we had a hell of a garden when the kids were still with us.

JT: (Laughs) Free labor yeah.

MK: But now, we don't have the kids there.

ST: Not much -

MK: And the wife was at home you know she raised the kids, but now she's at work too so it's -

ST: No time?

MK: No time to really do much.

JT: How many kids do you have?

MK: Six.

\section{JT: Six? Wow.}

MK: Now we got - we got 12 kids so, 18 grandkids.

JT: Yeah you could pull in a crop with that.

MK: Yeah just had the last ones was a set of twins.

ST: Oh my goodness. Congratulations grandpa yet again.

MK: Yep.

ST: That's a lot of kids to bounce on your knees.

MK: Yeah, dread to see Christmas coming up.

ST: I bet boy, yeah.

ST: You wish, I bet you wish you owned a toy store uh? 
MK: Just about.

JT: What kind of house was that, that you grew up in - that they tore down?

MK: Like I said the one I was born in actually originally it was like a little barn that they turned into a little house that they - when they first got married they started living in and kept adding on to - was all wood, wood structure.

JT: Yeah. All wood?

MK: Yeah

JT: Couple of rooms?

MK: Yeah

JT: Kitchen? Kitchen was inside or -?

MK: Yeah. The kitchen was inside, everything was inside from what - my time

JT: Right yeah yeah.

MK: That I can remember.

ST: Even an outhouse. You didn't have an outhouse?

MK: No. It was - from the time I can remember everything was inside plumbing.

JT: Electric oven?

ST: It was a good life.

MK: Yeah. Now before, before my time they had outhouse and stuff like that.

ST: Sure. Yeah.

MK: But by the time I came along it was, everything was inside.

ST: Right.
JT: Were there a lot of families from German descent around in that area, in Wetmore that you associated with?

MK: Yeah, yeah I would I would say most - the whole neighborhood was almost all German descended.

JT: You remember any of the other families that lived in that area?

MK: Yeah There's uh right next door was uh Wehe, W-E-HE. And uh there was Lu (?) Were kind of like right there on Starcrest. Was a family named Lookt (?).

ST: Uh uh. That's a good German name.

MK: And Carver - that was another family. There was two, two families that had land in between. I guess maybe 75 , between 75 and 100 acres in between, in that area there.

JT: Uh huh.

ST: Your last name was always spelled K-L-A-R?

MK: As far as I know, yeah.

ST: Sometimes the harder they become to pronounce the more they changed them on the boat. By the time you land your last name is spelled totally different than what you started out?

MK: Yeah.

ST: Sounds like in your case it was easy enough to remember.

MK: Yeah. No, as far as I know it was always yeah it was always K-L-A-R.

JT: Did uh, all the other families were they pretty much agriculture based or did they uh - they all had farms like y'all?

MK: Yeah, uh huh - cattle and farms.

JT: Uh huh.

ST: Did you raise any crops besides the garden you know just for home use? 
MK: Well we, mainly just for grazing for cattle.

ST: You had fields planted?

MK: Yeah, planted the fields for the dairy cattle to graze on - hay and stuff?

JT: Were there streams or ponds on the land that you used or fished?

MK: Mainly, wasn't any fish, just uh water the -

\section{ST: Stock tank?}

MK: - creek, that creek Mudd Creek whenever it came up that was about it?

JT: Wet season?

MK: Yeah.

ST: Did it flood a lot back in those days or did it stay dry like it did.

MK: No it was quite a bit of flooding

ST: Really. Did y'all get flooded out at all? Pretty high spot there.

MK: No. No, we never, we never had any problems getting flooded out, but uh the uh water goes underneath the railroad tracks right down there - it damn near touch the railroad tracks underneath.

\section{ST: No kidding.}

MK: Where Mudd Creek and Old Salado come together.

ST: That low spot yes.

MK: Of course, now with the new dam they built in there I doubt they ever have any problems anymore.

JT: Who had to be moved when the land was bought - did y'all move at all or - you said there was like a 3, y'all took out a 3 acre spot right $-\mathrm{y}$ 'all kept that?
MK: Yeah, we held that back out of the -. In other words, when the city bought all that stuff out, we just held on to those three acres.

ST: And you still own those acres right?

MK: Yeah.

ST: You still live there?

MK: That where we're at. That's where we live at.

JT: It was you and your parents and there was another house there is that right?

MK: My sister's.

JT: Your sister's.

MK: Which now my nephew, my sister's boy owns it.

ST: He's got a relative that lives there or - ?

MK: Yeah, he lives in the house now.

JT: That's great.

ST: It's good to keep some of the family still close.

MK: Yeah.

JT: Do you know if that was considered a lot of land that your family owned then or was that about average for people around there?

MK: About average, yeah.

JT: Did uh, how old were you when they bought the land to make the park?

MK: When the city bought it?

JT: Uh huh.

MK: Probably, 20-21something like that. 
JT: And you'd just been married is that right? Do you remember what year that was off the top of your head?

MK: About $64-65$. We got married in 62 I was 19 and it was couple of years after that. So 64,65 something like that.

JT: 19? That's right out of the chute. (laughs)

MK: (Laughs) Yeah.

JT: What's your wife's name?

MK: Norma.

JT: Norma.

JT: She uh from the Wetmore area also?

MK: No she's, fact is she's from the Woodlawn, Woodlawn Lake area

JT: Oh ok.

MK: Which is, her mother still lives over there. She just celebrated her hundred and one. Hundred and one year old. Celebrated her hundred and first birthday - still living by herself.

JT: Wow.

ST: Really? Holy cow. That's a tough woman right there. Must be also German?

MK: No she's Italian.

ST: Itlalian? No kidding? They make'em that hard headed huh?

MK: Well.

JT: What was your wife's maiden name?

MK: Ouvietta.

JT: Ouvietta. That's a give away right there.
ST: Yeah. My great, great grandmother, Francesca was Italian. We, you know in Europe, most everybody has you know a mixture of things in them. We got some Polish and Romanian, Hungarian, Italian yeah you name it, just about everything there. It's fun, more fun that way.

MK: Yep.

JT: Do you know if everybody in the family was for selling the land or some people didn't want to sell the land?

MK: Actually we, if you really want to know the whole story?

JT: Yeah.

MK: Nobody was ready to sell it.

ST: Really, no kidding.

JT: Huh, how come?

MK: The city, the city decided they wanted it, they were in the process of extending that airport.

JT: Oh, I see.

MK: And they flat told my dad - My dad told them he wasn't interested in selling and they flat told him, either you sell it or we'll condemn it.

ST: No kidding.

MK: So there wasn't, there wasn't no choice in it.

JT: Right.

ST: You mind if we put that in?

MK: It's up to you all if you want to.

ST: Well it's not going to get us in trouble and too, too late to get you in trouble.

MK: Yeah I don't think so.

ST: Won’t make any difference. 
MK: No.

JT: Do you remember who you're dad was dealing with when all that was going on? The mayor or city council?

MK: I don't remember names -

JT: Don't remember ok.

MK: - who was in there at that time.

JT: So the airport, they took the land for the airport first and then they too the land - was the park planned the same way, they just kinda - ?

MK: Uh huh. Well, what really T-ed me off the most was a couple of years after they bought all that land they put an article in the paper about the reason they bought that, bought that land was because they could buy it so cheap.

ST: Uh son of a - , you're kidding me

JT: Uh.

ST: After bribing everybody into selling it -

MK: Right.

JT: Wow.

ST: Pretty sad.

MK: That, that really took the cake - when they put that in.

ST: I'm sure some people bought it for real cheap afterward and made some money off of it, speculators - (inaudible).

MK: Yeah, oh yeah.

JT: So, that pretty much took all the land your family had except for those three acres is that right?

MK: Yeah.

ST: Wow.

JT: Were there any other families' land taken like that?
MK: Yeah well there the Boogh, Carver, everybody that was -

JT: All those?

MK: Yeah.

JT: Wow.

MK: There was one other farm that was right there on, which was uh, literally gone right through. It was a Poppy, a Poppy right there off that section - I think probably from Wetmore, but just about where the creek went through.

ST: Uh huh, yeah.

MK: - that area where their house was at. Trying to think of the name of that other family that up there off of uh, Jones-Maltsberger I cain't -

ST: Jones-Maltsberger extended from there over at that time.

MK: Yeah, oh yeah. The roads were all, all there. The only difference was at that time uh Thousand Oaks was uh Lockhill-Selma.

\section{ST: Wow.}

MK: It wasn't called Thousand Oaks, it was called Lockhill-Selma back in those days, quite awhile back there.

ST: Well we were looking at uh, recently we were putting together, actually we're doing some archaeological survey in the area they're going to expand the uh airport runways at Starcrest there just across the park and we're looking at early 1950s quadrangles from one of these city sheets like that. There were some houses in there just about right where the runway is right now that were there. Do, do you know who those who that family might have been?

MK: That was probably that Poppy -

ST: Oh, that Poppy ok. That makes sense, that makes sense. We actually did find some driveways and all that were still left I guess they didn't bulldoze those but anything that was still above ground hey flattened in getting rid of -

MK: Yeah. 
ST: Wow. Change overnight, people's lives (inaudible).

MK: Yeah. Further down there was more, there would have been, I don't know if they would still be in that area or the airport has that property or if that's already over where the stadium is at - there used to be some uh Stubees.

ST: Stubee's? Yeah, that's another good German name.

MK: - that used to live in that area there. That may be a little further over already to where they extend that northeast side of the McAllister -

ST: McAllister - yeah.

MK: Yeah McAllister Stadium already.

ST: Did y'all used to get together regularly with those neighbors or didn't see them much?

MK: Uh, once in awhile. Mainly, mainly on Sundays -

ST: At church?

MK: Or that and uh, Sundays we usually uh the family - the Klars -

\section{ST: Get together?}

MK: Yeah, at one, one or the other brother's houses there every Sunday. Well, like my brothers I remember - I wasn't one of the lucky ones that inherited any of the music abilities but uh -

ST: This young man here is a musician himself.

MK: Really?

JT: Yeah.

MK: I tried like hell to pick up how to play the guitar and stuff, but I never did, never did uh, never had the patience to sit down and learn.

ST: Wasn't a calling.
MK: But uh my brothers were uh, one of my brothers played the guitar and the other one damn near play anything else around the uh, either horns or strings. He was real good at any of it and uh, they'd always -

ST: Did he become a professional musician or - ?

MK: No. No, he never did do anything with it. He just -

ST: Just for enjoyment.

MK: Just enjoyment and uh we'd always - I can remember when I was younger we'd get together and all, Sunday afternoons and play, they'd play music. Nowadays, nowadays nobody's got time for any of that. You know, when do you do anything like that anymore?

ST: Usually there's more on the weekends than there is in the week, gotta catch up and by the time Monday rolls around you're as tired as you were Friday.

MK: Right. Exactly.

JT: What kind of music did they play? Was it country music?

MK: Yeah, I think it was - Westerns.

JT: Do you remember uh, any other kind of music, any German music being played or - ?

MK: Oh yeah. My uncle on my mother's side Shale uh was Hare Loius and his Oompa band.

JT: Oh really.

MK: Yeah. They made, cut records and stuff.

JT: What was his name Hal Loius?

MK: Hare Loius, that was the name of his band. Name's Shale -

JT: Oh ok.

MK: - was his name, but his-

JT: Accordion player? 
MK: I think he played the cornet.

JT: Ok.

MK: But he had a complete band.

ST: They played in the San Antonio area?

MK: Yeah. San Antonio, New Braunfels.

ST: Yeah yeah. New Braunfels's - right there and Gruene. Was Gruene around then, back then?

MK: Yeah. Gruene was, Gruene was around a long time.

ST: Big German enclave right there.

MK: Yeah.

JT: Do you remember any other uh, folks living around, were there Hispanics living in Wetmore community at that time or was it all pretty much German?

MK: There were a few Hispanics around.

JT: Yeah, yeah.

MK: Not, not a whole lot - 2, 3, 4 families maybe.

JT: Right.

MK: And uh I think there was one or two colored families that lived back up on what they called Oor, Oor Lane. That's back where uh what's that-cement, Capital Cement?

ST: Yeah uh, the cement, crushing and -

MK: I think, I don't know if they still call that Oor Lane, Oor?

ST: Doesn't ring a bell. I don't know if they call it that -

MK: Bulverde, Bulverde Road - and when you get on the other side of Thousand Oaks, they used to call that Oor Lane.

ST: Oh ok. I don't think it's called that -
MK: I don't think they call anymore. There used to a couple of families, colored families that lived up in there.

JT: Do you remember any the, like the Hispanic families, did they work on farms around there? Do you remember what - ?

MK: I don't remember exactly what, what they did.

ST: Any, any Polish families made it up this far?

MK: No, not that I can remember.

JT: How long did you work in that bowling alley?

MK: Just in the younger years.

JT: Yeah.

MK: Setting up pins.

JT: Pin monkey?

MK: Yeah.

ST: Could've been worse.

JT: Probably easier than farm work huh?

MK: Yeah, it's quite a bit easier than hauling hay or something like that.

JT: Ugh, that's the worst job ever.

MK: It can get rough.

ST: Is there any way we can get a, take a closer look at this, make some copies of pages you have there? I know these are your very, most precious documents and I'd rather not touch them -

MK: Yeah.

ST: And I - interesting to get a little bit more of the history.

MK: I don't know exactly what uh - 
ST: Yeah I have no idea either - just, I don't know what, if it's even useful or not

MK: Yeah.

ST: It'd be fun to sit down with it, look through it.

At this point, the interview concluded with a discussion of copying Mr. Klar's land records and the publication of this interview. 



\section{Chapter 5: Summary and Recommendations}

Between September 19 and 22, 2005, the Center for Archaeological Research performed a 100 percent pedestrian survey within selected portions of McAllister Park. The Parks and Recreation Department of the City of San Antonio is planning a series of improvements to existing facilities and the construction of new facilities within the park boundaries. The proposed improvements and facilities are planned for 11 areas. Three of the areas (Areas 2, 5, and 7) did not warrant archaeological survey. Improvements in the areas not included within the 100 percent pedestrian survey consisted of trail repairs (Areas 2 and 7) and paving an existing temporary parking area (Area 5). The remaining eight areas were subject to the pedestrian survey.

Forty-five shovel tests were excavated within the eight APEs. In Area 1 four shovel tests (ST 1-4) were excavated, with one isolated find (a flake) recorded in Level $2(10-20 \mathrm{cmbs})$ of Shovel Test 3. Area 3 contained no cultural material in the four excavated shovel tests (ST 42-45). Three shovel tests (ST 18-20) were excavated in Area 4 along Lorenz Creek; no cultural material was encountered. One isolated find was recovered from Area 6, where five shovel tests (ST 37 41) were excavated. It consisted of a piece of lithic debitage in Level 2 of ST 39.

Five shovel tests were excavated in Area 9, with no evidence of cultural material (ST 5-9). The northern portion of 41BX959 is within the southern portion of Area 9, but further work is not recommended at 41BX959. Area 10 had evidence of disturbance and a single piece of recent green glass was recovered from one of the seven shovel tests (ST 14, Level 1) excavated there. Thirteen shovel tests were excavated in Area 11. The northeast portion of the area was disturbed and no cultural material was encountered in the shovel tests. The old fence line that was encountered in Area 11 may be associated with homesteads that appear on a 1953 version of the Longhorn, Texas USGS 7.5'quadrangle map.

In conclusion, the pedestrian survey of areas within McAllister Park resulted in documenting two isolated finds and encountering the northern portion of 41BX959 on the southern portion of Area 9. Furthermore, the fence line encountered in Area 11 may be evidence of historical land use. Given the lack of cultural materials within the eight APEs surveyed and tested and given the lack of integrity of the portion of 41BX959 found in Area 9, further archaeological work is not recommended within the APE tested during the project and it is suggested that the proposed developments to McAllister Park proceed as planned. 



\section{References}

Figueroa, A. and J. Thompson

2005 Intensive Pedestrian Survey of Three Tracts to be Impacted by the Planned Expansion of the San Antonio International Airport, Bexar County, Texas. Archaeological Report, No. 357. Center for Archaeological Research, The University of Texas at San Antonio.

Fox, A. A.

1973 An Archaeological Survey of the Northeastern Preserve and J Street Park San Antonio, Texas. Texas Archeological Research Laboratory, University of Texas at Austin.

1977 An Archaeological Assessment of the San Antonio 201 Wastewater Treatment Project. Archaeological Survey Report, No. 41. Center for Archaeological Research, The University of Texas at San Antonio.

Hester, T. R.

1995 Early Archaic Chronology in Southern Texas. La Tierra 22(1):4-5.

Hester, T. R., F. A. Bass, Jr., A. A. Fox, T. C. Kelly, M. F. Chadderdon, and E. S. Harris.

1974 Archaeological Survey of Areas Proposed for Modification in the Salado Creek Watershed, Bexar County, Texas. Archaeological Survey Report, No. 3. Center for Archaeological Research, The University of Texas at San Antonio.

Potter, D., and S. Black

1995 Archeology Along the Wurzbach Parkway: Module 2 Initial Testing and Evaluation of Five Prehistoric Sites in the Upper Salado Watershed, Bexar County, Texas. Studies in Archaeology 18. Texas Archeology Research Laboratory, The University of Texas at Austin.

Taylor, F. B., R. B. Hailey, and D. L. Richmond

1966 Soil Survey of Bexar County, Texas. U.S. Department of Agriculture Soil Conservation Service. The Soil Conservation Service, Washington, D.C.

Texas Historical Commission (THC)

2005 Texas Archeological Sites Atlas, http://www.pedernales.thc.state.tx.us/, accessed October 2005.

Tomka, S.

2002 Data Recovery Excavations at 41BX1412: A Multicomponent Site in McAllister Park, San Antonio, Bexar County, Texas. Archaeological Survey Report, No. 324. Center for Archaeological Research, The University of Texas at San Antonio.

Tomka, S. and R. C. Robinson

2000 The McAllister Park Roadway System Extension Project, San Antonio, Texas. Archaeological Survey Report, No. 301. Center for Archaeological Research, The University of Texas at San Antonio.

Vines, R.A.

1960 Trees, Shrubs, and Woody Vines of the Southwest. University of Texas Press, Austin.

Zapata, J. E.

2002 McAllister Park Parking and Road Extension Project, San Antonio, Bexar County, Texas. Letter Report, No. 140. Center for Archaeological Research, The University of Texas at San Antonio. 
